\title{
The Role of Materially Heterogeneous Entities in the Entrepreneurial Network
}

\section{Third Revision}

\section{Submitted to Industrial Marketing Management call: Start-ups and business networks - An integrative view on new ventures}

\begin{abstract}
Few researchers have examined empirically the dynamics of human-non-human networking and its importance for strategic outcomes, particularly in the field of entrepreneurship. In this paper, we use Actor-Network Theory to observe and investigate the role of materially heterogeneous entities in the entrepreneurial network. Building on the results of a four-year, multi-case study, this paper describes how an entrepreneurial network, beyond its social nature, is also a socio-material constellation. The symmetric treatment of human and non-human actors enables us to move away from the figure of the heroic entrepreneur. Our findings reveal various roles that the heterogeneity of actor-networks can play in the entrepreneurial process. We see on the one hand their power to attract and recruit new allies when they are aligned with the entrepreneur's vision, and on the other their ability to repel and block the new venture creation process when they fail to effectively translate what the entrepreneur has in mind.
\end{abstract}

Keywords: New venture, actant, social networking, Actor-Network Theory

\section{Introduction}

Networking has been identified as a critical entrepreneurial behavior (Reynolds, 1997) that can help explain why certain individuals succeed or fail in creating new organizations (Honig, Davidsson \& Karlsson, 2005). More recently, it has been asserted that an entrepreneur's network can relate to the development, but not necessarily the success, of the venture (Tello, Yang \& Latham, 2012). Either way, the facilitation and support of effective networking activities is one of the most valuable ways to nurture businesses and is particularly important for nascent entrepreneurs due to the idiosyncrasy of their initial needs (Davidsson \& Honig, 2003). For those in the early stages of business start-up, networks are not just about forming strategic alliances - ensuring access to necessary skills, expertise and resources—but also about being aware of business opportunities, 
raising the profile of the new venture, and positioning it appropriately to be able to influence future sector developments (Karataş-Özkan \& Chell, 2010). Furthering our understanding of nascent entrepreneurs' networks and learning how best to facilitate them represents an important activity for future entrepreneurship research (Davidsson \& Honig, 2003).

A recent interesting development in network research is the growing number of scholars who acknowledge the "inherent inseparability" of the social and material aspects of organizational work (Orlikowski, 2007). This notion is becoming more prevalent in management research (La Rocca et al., 2016). However, few researchers have examined empirically the material/social networking dynamic in the field of entrepreneurship. Since entrepreneurship research widely acknowledges the relevance of interactions between individuals, firms and the environment (Hitt et al., 2011; Westhead \& Wright, 2011), it is somewhat surprising that so little has been said about how social and material entities interact to influence this process, especially in the context of new start-up creation (Doganova \& Eyquem-Renault, 2009).

In this article, we seek to further understand the dynamics of entrepreneurial networks and employ an empirical inquiry with a practice perspective. Given the nature of our focus, we use ActorNetwork Theory (ANT) as our theoretical lens and methodological guide. ANT (Callon, 1986) enables us to observe and investigate the constitution of networks and their variation over time as well as their capacity to perform start-ups (Hagberg \& Kjellberg, 2010). We conceive of agents as "provisional outcomes, as collectives, or networks of associated materials" (Araujo \& Kjellberg, 2009: 207). These agents may be devices, individuals and/or organizations. We conceptualize agential capabilities as the "competencies, abilities and skills" that they embody (Hagberg \& Kjellberg, 2010: 1029). 
Business start-up creation can be viewed through a practice lens (Callon \& Law, 1995; Shove \& Araujo, 2010; Shove \& Pantzar, 2005; Hagberg \& Kjellberg, 2010; Lawlor \& Kavanagh, 2015), where the entrepreneurial process is understood to come about through the constitution of agents (Steyaert, 2007). In line with this, we propose that it is important to go beyond conceptualizing these agents, and entrepreneurial networks, as purely social (meaning "people"). A more enlightened understanding of entrepreneurial network dynamics needs to incorporate non-human elements in the analysis. An entrepreneurial network can be considered as a constellation of agents and associated materials. This gives rise to an important research question: "What are the roles of materially heterogeneous entities during the networking start-up phase?"

To address our research question, we applied a longitudinal case study approach to three French technology start-ups. We incorporated a socio-technical analysis (Latour, 1991) of the networking process in entrepreneurship. We also developed an "abridged script of a socio-technical path" (Latour, 1991) and calculated socio-technical indicators to plot graphs depicting the dynamics of each case.

While there have been calls for greater understanding of the role played by socio-materiality (Shove \& Araujo, 2010; Lamine et al., 2016), there is a more specific need to improve knowledge about how interactions between human and non-human actors underpin entrepreneurial performance (Jones et al., 2010). In addressing these calls, we contribute to knowledge and understanding in the following ways. First, we go beyond the purely social conception of the entrepreneurial network to show that the heterogeneity of agents is critical for start-ups. Our research shows that entrepreneurs are powerless without non-human actors. Heterogeneous actor-networks are more active than those 
composed only of human entities. Second, our analysis provides further support for previous research on the capacity of agents to perform (Andersson et al., 2008; Hagberg \& Kjellberg, 2010). The trajectories of the three cases show the capacity of agents to act programmatically (Hagberg \& Kjellberg, 2010), including their ability to help start-ups escape uncertainty and reduce information asymmetry. Thus, the capacity of agents is instrumental in exploring/exploiting entrepreneurial opportunities and significantly impacts on the survival of start-ups. Furthermore, we show that the cumulative capacities of agents become a structuring force of the hybrid entrepreneurial network by feeding the entrepreneurial process with resources, skills and competencies (Hoholm \& Olsen, 2012). Finally, we expose a darker side of entrepreneurial networks and show that although agents may be aligned and compliant with the entrepreneur's vision, they can also display non- and anti-programmatic behaviors (Helgesson \& Kjellberg, 2005).

The paper is structured as follows. First, we introduce literature on the entrepreneurial network and ANT that provides the theoretical background for our study. Second, after presenting our methodology and our empirical data, we continue with a description of the socio-technical analysis applied in this research. Third, we present the results of the study and interpret the socio-technical graph of the three cases to explain the importance of materially heterogeneous entities during the complex start-up phase. Finally, we conclude with a discussion of our findings and suggestions for future directions on entrepreneurial network research.

\section{Theoretical grounding}

\subsection{Entrepreneurial networks: human and non-human actors}

Networks play an important role in influencing entrepreneurial processes and outcomes (Hoang \& Antoncic, 2003). They are thought to play a particularly significant role in nascent entrepreneurship 
(Lee et al., 2001, Mosey \& Wright, 2007; Aaboen et al., 2013; La Rocca et al., 2013; Elfring \& Hulsink, 2003), when getting that first sale or making a profit often depends on the nascent entrepreneur's social ties. Indeed, entrepreneurs with a broad, diverse and supportive social network are more successful and their ventures have greater chances of survival and growth (Brüderl \& Preisendörfer, 1998). Thus, entrepreneurial performance is seen to depend on the ability and capacity of nascent entrepreneurs to mobilize their social network (Baron \& Tang, 2009).

An interesting development in social network theory over time has been its broadening of focus to include not just relationships between groups of people, but also non-social relationships (Brand, Croonen \& Leenders, 2012). This comprehensive view of actors has extended to entrepreneurship research on networks. Scholars adopting an "entrepreneuring" perspective (Steyaert, 2007; Johannisson, 2011) consider entrepreneurship as "a new form of connectivity and assemblage where both human and non-human elements (actant) are included to give form to the trajectories of a world in its becoming" (Steyaert, 2007: 471). Throughout the entrepreneurial process, entrepreneurial activities are objectified in material entities (Orlikowski \& Scott, 2008), such as PowerPoint slides, prototypes, written documents, audio and video recordings and machines. Entrepreneurial outcomes cannot therefore be explained with reference only to the social. Nonhuman actors also play a part in shaping outcomes (Jones et al., 2010). Thus, a complete understanding of an entrepreneurial network calls for "further analysis of connections and associations made between heterogeneous actors" (Hernes, 2007: 74).

Despite a vibrant stream of research addressing the impact of networks on entrepreneurial outcomes, there is a notable lack of process-oriented studies in which networks are the dependent variable (Lamine et al., 2015). Indeed there is a dearth of knowledge concerning the process dynamics of network development in entrepreneurship (Jack et al., 2010). More specifically, there 
is a need to explore further the heterogeneity of actors in entrepreneurship. We need a conceptualization of entrepreneurial networks that is sensitive to the hybrid combinations of material objects, individuals, groups and organizations (Hagberg \& Kjellberg, 2010). Here, we use Actor-Network Theory (ANT), as well as more specific theoretical contributions related to heterogeneous actors, to yield new insights into the entrepreneurial networking process.

\subsection{Actor-Network Theory (ANT) ${ }^{1}$}

ANT researchers seek to understand how innovative projects are collectively constituted (Akrich, 2002a, b; Harrisson \& Laberge, 2002). Successful innovation depends on the diverse associations and collaborations that take place between several key actors (Callon, 1986; Latour, 1991). Opportunities, contacts and production possibilities emerge as various actors commit and cooperate in networks, rendering the start-up process more efficient and effective as it proceeds.

Networks are often described as sets of nodes and relationships (Steier \& Greenwood, 2000). From an ANT perspective, a node is an entity that interacts with other entities or serves as an intermediary between them. The originality of ANT is that an actor-network is made up of both human and nonhuman entities called actants (Law, 1986). ANT emphasizes the relevance of material artefacts in social network building (Latour, 1991), which means that researchers who study networks must

\footnotetext{
${ }^{1}$ For readers, non-familiar with ANT, we suggest the following reading:

- Law, J. (2008). Actor Network Theory and material semiotics. In B. S. Turner (Ed.), The New Blackwell Companion to Social Theory. Oxford, UK: Wiley-Blackwell, doi 10.1002/9781444304992.ch7.

- $\quad$ Latour, B. (1996). On actor-network theory. A few clarifications plus more than a few complications, Soziale Welt, 47, 369-381.

- $\quad$ Akrich, M., \& Latour, B. (1992). A Summary of a Convenient Vocabulary for the Semiotics of Human and Nonhuman Assemblies. In W. E. Bijker, \& J. Law (Eds.), Shaping Technology/Building Society: Studies in Sociotechnical Change. Cambridge: MIT Press.

- $\quad$ Latour, B. (1986). The powers of association. In Law, J. (Ed.), Power, Action and Belief: A New Sociology of Knowledge. London: Routledge \& Kegan Paul (pp.264-280).

- $\quad$ Latour, B., \& Woolgar, S. (1979). Laboratory Life: The Social Construction of Scientific Facts. New Jersey: Princeton University Press.
} 
deal with humans and non-humans on the same terms and make no a-priori distinction between them. This is not to say that human and non-human actors are the same, but that they are both fundamental elements of an actor-network (Latour, 1991). A good example of this can also be found in Latour's (1994) discussion of the classic US gun debate ${ }^{2}$ : do humans or guns kill? Latour's point is that the two form actor-networks that are capable of actions that neither of the entities is capable of on its own (Latour, 1994: 31).

The ANT perspective does not imply that all kinds of material actors should be indiscriminately included in entrepreneurial process studies, but rather suggests that considering them as inactive or not affecting the entrepreneurial activities is ill-advised.

The use of ANT to study how networks are developed and mobilized seems particularly relevant when applied to the entrepreneurial process. The theoretical and methodological tools of the ANT approach provide useful insights into network dynamics, and by extension, emphasize shifts in the trajectory of an entrepreneurial situation. To study the development of temporarily stable networks supporting innovative projects, ANT researchers have defined a procedure that relies on a sequence of stages called "the chain of translation." This is a process leading to a situation through which all relevant actants must pass for their interests to be served (Callon, 1986). This procedure makes it possible to plot visually the dynamic trajectory of the constitution and variation of an entrepreneurial network (Akrich, 2002a, b). By way of analogy, such graphs can be likened to video footage of a dancer (including stage, props and audience) as opposed to a snapshot of one dance move in one place at one moment in time.

\footnotetext{
${ }^{2}$ We thank an anonymous reviewer for pointing out this example.
} 
Another methodological feature of ANT is its advocacy of case studies as an effective way to enhance understanding of the entrepreneurial process. Several ANT researchers have already conducted case studies with a practice-oriented perspective, including Callon's famous example of the Saint Brieuc Bay scallops (Callon, 1986), the Diesel engine, the Kodak story (Latour, 1987), and the Zimbabwe bush pump (Laet \& Mol, 2000).

\subsection{Entrepreneurial networks: A practice perspective}

From a practice perspective, the distributions of competencies between human and non-human entities within and between hybrid collectives are of particular interest (Callon \& Law, 1995; Shove \& Araujo, 2010; Shove \& Pantzar, 2005; Hagberg \& Kjellberg, 2010; Lawlor \& Kavanagh, 2015). This focus on human-non-human interaction fits well with ANT approaches in the context of startup creation (Lamine et al., 2016). ANT acknowledges the performative power (Doganova \& Karnøe, 2015) of actants and can help us move away from the tendency to ascribe innovations to quasi-heroic entrepreneurial actors (Nicolini, 2010).

Entrepreneurs and their projects are like two revisable expressions of a desired future. They are two temporary states of the final outcome that mutually define one another (Bruyat \& Julien, 2001). The individual is a would-be entrepreneur and the project is a would-be object that may later become a stable and viable firm, just as it may abort at any time in the process and lead to the disappearance of the entrepreneurial situation (Fayolle, 2007). When it comes to analyzing the entrepreneurial process, nascent entrepreneurs and their innovative projects are effects created in the network of associated social and material actors that should be considered simultaneously.

In the entrepreneurship field, while some researchers have shown the importance of human actors' social skills and competencies (Baron \& Markman, 2003), few have studied the broader agential 
capacities (Hagberg \& Kjellberg, 2010) in the context of new venture creation. This is somewhat surprising given that recent studies suggest that the role of materiality needs to be unpacked and understood better (Okhuysen \& Bechky, 2009; Orlikowski, 2007; Clarke, 2011; Nicolini, 2012), especially when entrepreneurial performance is underpinned by interactions between human and non-human actors (Lamine et al., 2016).

However, in the business field there is a fervent research stream that considers the emergence of markets through practices involving interactions between human and non-human actors (Araujo, Kjellberg \& Spencer, 2008; Harrison \& Kjellberg, 2010; Doganova \& Karnøe, 2015; La Rocca et al., 2016; Araujo, 2007; Kjellberg \& Helgesson, 2007). It draws inspiration from a line of research in economic sociology that has examined the construction of markets, defined as arrangements of heterogeneous elements (Doganova \& Karnøe, 2015). The literature on the shaping of markets that has applied ANT as a methodological approach for explaining emerging markets is useful for our research and provides a source of inspiration for the study of the emerging start-up. In Table 1 we summarize some key empirical studies inspired by an ANT perspective.

\section{Insert Table 1 here}

Drawing on the studies presented in Table 1, and our argument for the utility of applying an ANT approach to entrepreneurial networks, we propose the following research question: "What are the roles of materially heterogeneous entities during the networking start-up phase?"

\section{Research setting and design}

\subsection{Research approach}


Given the exploratory nature of our research, we chose a case study approach to address this question. As noted by Dubois and Araujo (2004), the case study method is suitable for research on networks due to its flexibility, which allows for boundaries to be drawn gradually and for iterations to be made between theoretical grounding and empirical data (Doganova \& Karnøe, 2015).

In short, a case study approach is considered appropriate here given the scarcity of empirical work investigating the heterogeneity of entrepreneurial networks from a dynamic perspective (Lamine et al., 2016). According to Stake (2003), case studies have become one of the most common ways of conducting qualitative inquiry and they "are not a methodological choice, but a choice of what is to be studied" (Stake, 2003: 435). We opted for an in-depth case study approach (Sandberg \& Tsoukas, 2011) to enhance our knowledge of the role of materially heterogeneous entities during the earlier stages of the entrepreneurial process.

According to O'Donnell et al. (2001), it is imperative that networks be studied over time. Similarly, Hoang and Antonic (2003) argue that entrepreneurial studies should be longitudinal and show how network content, governance and structure emerge over time. Stam et al. (2014: 169) also argue that "future studies should employ longitudinal data to disentangle the causal effects. In so doing, scholars may draw on recent methodological advances such as actor-based network models [Snijders et al., 2010] to examine how changes in entrepreneurs' personal networks direct, and are shaped by, the evolution of their firms."

In this paper we have opted for a longitudinal perspective (Pettigrew, 1992) and a systematic combinatory approach by constantly going back and forth between theoretical ideas and the constitution of entrepreneurial networks (Dubois \& Gadde, 2002, 2014). In networking dynamics research, case studies have relied on ethnography and participant observation (Azimont \& Araujo, 
2007, 2010; La Rocca et al., 2016), archival materials (Kjellberg \& Helgesson, 2007) or interviews and document analysis (Doganova \& Karnøe, 2015). Although we used participant observation in our research (e.g., incubators' meetings, entrepreneurial team discussions or scientific experiments), the analysis of interviews, documents and material artefacts was the main and most appropriate research design. This design allows us to deeply understand dynamics of the sociotechnical network. For each case our unit of analysis was the network of actors and not a single site (Doganova \& Karnøe, 2015: 24).

\subsubsection{Cases: Technology-based ventures}

Through purposeful sampling (Gartner \& Birley, 2002), we identified three technology-based new ventures to examine. These ventures showed diverse characteristics in terms of the entrepreneurs' background, the type of technology developed and the project outcomes. The study was conducted over a four-year period, from September 2007 to October 2011, during which time we were able to observe the entrepreneurial ventures closely. Over that period 39 formal semi-structured and open-ended interviews were carried out.

All nascent entrepreneurs in our sample benefited from a French technology-based incubator, ensuring their entrepreneurial commitment in the new technology-based firm (NTBF) creation process (Fayolle, 2007) and allowing us to study the three cases in a similar environment. They represent three industrial sectors: space nanotechnology, animal biology and medical biology.

The three technology-based ventures were identified and selected among a list of 21 incubated projects during a meeting with all the incubator's manager and advisors. The criteria we chose to select this project were:

the new venture creation must be the first entrepreneurial experience for the entrepreneur; 
- $\quad$ the company was scheduled to be set up by April 2009 (estimation);

- $\quad$ the existence of a leader in the case of creation by a small entrepreneurial team;

- $\quad$ the signature of the incubation agreement.

\subsection{Data collection}

Given our conceptual starting points, our data collection process was influenced by ANT contributors who have advocated a detailed study of actions over time (Callon, 1998; Latour, 1991). Our ANT approach meant that rather than focusing on one or other dimension, we collected data on the network created by the project, the entrepreneur and the entrepreneurial context (Bruyat \& Julien, 2001). Consequently, a large amount of data relating to the entrepreneurial process over time was collected and analyzed. Data were collected using three main information sources: semidirected interviews, documents and material entities, and participant observation (see Table 2).

$\underline{\text { Semi-directed interviews }}$ Semi-directed interviews constituted our primary source of data. We opted for open questions to get insightful and in-depth descriptions of the situations concerned. However, the questions were formulated carefully and interview protocols and guides were developed in line with our process-oriented approach and ANT framework. We targeted three main sources of information: entrepreneurs, their incubator advisors and their incubator manager, who were used as intermediaries in accessing the entrepreneurs and getting to know their projects. Our sample was composed of nascent entrepreneurs with innovative projects in sectors we were unacquainted with, so we sought the views of incubators' advisors and managers to improve our familiarity with the field, gain credibility, and build trust with the project bearers.

For each project we scheduled on average four interviews per year, based on three interview guides. The first guide was developed for the project advisor, and focused on the technical and economic 
specificities of the project, the entrepreneur's profile and the industrial sector in which the individual/project dyad was embedded, to learn about its characteristics and terminology. The second guide was used for the initial interviews with the nascent entrepreneurs. It was designed to help open the black box. ${ }^{3}$ During this initial interview, we asked entrepreneurs about their profiles, the story behind the project, the business model of the future firm, and the skills and resources required, with a focus on their networks and their evolution over time. A third guide was put together for the third phase of our study, which consisted of follow-up interviews with the nascent entrepreneurs to monitor the evolution of their project over time. This third guide was divided into three parts, one focusing on the workability of the project, and including items such as the conditions for success, skills, resources, and the desired final script. The second part was devoted to the strategies adopted to deal with problems and opposition and included questions about the evolution of the entrepreneurs' networks, emerging controversies, negotiations, adjustments, transformations, and disputes. The third and final part of the guide concerned the conditions of feasibility of the project, and discussed potential obstacles as well as evidence of feasibility, including expert studies and tests.

All of the entrepreneurs in our sample agreed to the recording of their interviews, on condition that we sign a confidentiality agreement. They also asked to review the transcripts to ensure that their innovations were protected. Their fear of disclosure posed some problems during the initial interviews, as interviewees refused to discuss what they considered highly sensitive information; it was only at the second interview stage that trust was finally established and the barrier removed.

\footnotetext{
${ }^{3}$ At the time we started our study, the project was a story, a series of events that we had not witnessed; it was therefore indispensable to open this black box to understand better the background and evolution of the project.
} 
Recording made it easier to concentrate on controlling the dynamics of the interview, asking for clarification or explanation, without having to worry about missing information.

This interview process produced rich descriptions from participants. We later performed a content analysis of their accounts. Using NVivo software, a data analysis grid was developed using the following coding procedure. First, we defined free nodes based on our research question. The nodes were first defined regardless of any relationship that might exist between them. Based on this initial and relatively unstructured phase of data processing, we called in an independent third-party researcher who was unacquainted with the cases studied, to proceed with the coding of all the interviews, while we also proceeded with our own coding. There were three phases in this double coding procedure. We first coded the data from the entrepreneurs' initial interviews independently, following which we compared our lists of codes. Based on these results, we finalized the list. Both lists were analyzed and discrepancies discussed to understand their causes. The list of codes was ultimately adopted by the two researchers before they proceeded with coding the remaining interviews independently.

We were also able to retrace and reconstruct the different phases of the process, through comprehensive analyses of the project trajectories.

Material entities: We examined prototypes, written and video documents (business plans, presentation videos, test videos, applications for entrepreneurship contests, press articles and different versions of prototypes), which have the advantage of being produced outside the context of the study. They are, as a result, unbiased by any modification in the interviewees' behavior, as is sometimes observed in research contexts. Gathering secondary data from written documents is useful in qualitative analysis for enhancing understanding and providing deeper insights into the 
situation studied, including external perspectives on the subject (expert opinions, market studies conducted by specialized agencies, committee reports). Our process-based approach, backed by the examination of materially heterogeneous entities, enabled an enhanced understanding of the chronology of events that occurred over the four-year period.

Observation: Previous research has emphasized the relevance of participant observation for network research (Bøllingtoft, 2007; Jack et al., 2010). Therefore, as a complement to the interviews, we took part in meetings and visits to the various research laboratories. This helped us to understand the situational contexts in which the projects had emerged. We also attended the incubator tenant selection committee, during which we met all the members involved in the incubating program. We visited the places where the projects were developed technically; we attended prototype-testing sessions and simulations of the technologies developed, while meeting other actors in the entrepreneurs' networks. This complementary observation method, well suited to case study research, was performed without the other actors present knowing who we were, or what our purpose was. We were not presented as researchers but as visitors invited by the entrepreneur. This enabled us to study our objects in their natural environment and reduce the bias that could result from potential changes in behavior. Besides the methodological advantages, the three entrepreneurs were keen not to reveal our role to other participants.

\section{Insert Table 2 here}

\subsection{Socio-technical analysis}

ANT suggests that any description of an innovative project is a work of fiction that varies over time. However, the study of any new start-up requires a preliminary description and understanding of its history. Most importantly, the new start-up is also described in terms of its present and 
desirable future (albeit a fictional one) with particular regard to its economic and technical feasibility.

According to Akrich (1992), there are four levels of description characterizing any innovative project:

1. The desired final script ${ }^{4}$ : This is used to define the conditions of (de)construction of the future new start-up and to determine the conditions in terms of the desired end state.

2. The temporal trajectory: This tracks the progress and constitution of the actors' network, bridging the gap between the current situation and the desired future state.

3. The problematization: This is the system of association between entities. This system defines the identity of that association and the problems that may stand between these entities and each of their respective interests.

4. The likely future world: This is the hypothetical socio-technical environment that conditions the emergence of a new start-up.

The socio-technical analysis provides relevant tools to describe an innovative entrepreneurial project (which is not based on a fixed prior definition of the entities involved) and also manages to describe fluctuations. However, a new start-up seeks endless committed relationships that develop in a continuous process over time. Therefore, the exhaustive description is unobtainable. Consequently, the question that arises is: How can we explain this dynamic description in the

\footnotetext{
${ }^{4} \mathrm{~A}$ script is an imaginary scenario or format of a desirable future world through specific articulation of desired elements and objects. It is the entrepreneur's vision of the future world that the entrepreneur will be inscribing in the technical content of the new venture.
} 
context of a complex and changing relationship? An answer to this question is suggested by the use of socio-technical graphs.

Socio-technical graphs allow us to map a network's evolution over time as a set of indexes and curves. The objective of this method is to improve and simplify the readability of networks, while offering a genuine dynamic description. "It can thus help to solve two of the most irritating problems encountered in both historical and contemporary science studies: first, the impossibility of comparing different case-studies and second, the impossibility of obtaining quantitative measures adapted to the local, contingent, and circumstantial characteristics of networks" (Latour et al., 1992: 2).

In what follows, we summarize the socio-technical method applied to our three cases. The logic flow chart of the protocol used in socio-technical analysis is presented in Figure 1.

\section{Insert Figure 1 here}

Based on the data analyzed and considering the story of each case we abridged the socio-technical description by successively recording all the new actors, human or non-human, single or collective. Table 3 summarizes the evolution of the network-actors over time. In column 1, the order of the entrepreneurial network's version is numbered $V(1)$ to $V(n)$. The number of entities of each version (N) is mentioned in column 2. Finally, in column 3, the dynamic of the network's structure is abridged. For confidentiality reasons, we gave a shortened name to each actor whose position corresponded to the order in which the actors entered the scene.

Insert Table 3 here 
In this next step, we merely recorded the number of new actors arriving, leaving, or returning to the narrative. This coding allowed us to calculate the indicators of network size, allies (entities acting programmatically) and new allies.

The indicators are essentially three ratios that make it possible to measure:

1) Yield index (Y), ${ }^{5}$ which refers to the "social profitability" of the project. The project is highly socially profitable when the index equals 1 and not at all profitable when it is zero. This index is calculated by dividing (the cumulative number of the aggregate of new actors) - (the cumulated number of lost new actors). The Yield index thus obtained measures either the capacity of a project to attach itself to the majority of the actors it mobilizes when the index tends toward 1 or, on the contrary, its tendency to visit a large number of new actors without fixing itself anywhere, when the index tends toward zero. (Latour, 1992).

2) Index of negotiation (IN), or the need for negotiation. This assesses the ability of the project to transform all the mobilized elements that visit the network into a stable actors' network from one version to another. If all the new elements are transformed into actors, then the project does not need to be renegotiated because it can attach all new visitors. In this case, the IN rate is low and reflects stability in the network. Conversely, if the project has many new visitors but struggles to attach them to its network, the IN rate is high and reflects network instability. In this case, the project needs to be deeply renegotiated.

3) Index of reality (R): This index measures the "resistance [needed] to be able to move from one network version to the next without putting what it already acquired into question." It measures the number of actors maintained from one network version to the next. So, if the rate equals 1 , the

\footnotetext{
${ }^{5}$ See Appendix 1.
} 
project has succeeded in preserving all actors. However, if the project loses some allies when the network moves from one version to the next, the indicator $\mathrm{R}$ will fall.

Appendix 1, with detailed case-specific illustrations, and Table 2, show how these indices were calculated.

Based on the interpretation of the socio-technical indicators and our own reading of the entrepreneurs' verbatim accounts, we selected the actants that met the four following criteria:

- Entities that acted programmatically, in accordance with the program of action ascribed to them.

- Entities that were sources of problems.

- Entities that influenced the networking path.

- Entities that impacted the outcomes of the entrepreneurial process.

In the next section, we present our findings and theoretical contributions based on the cases observed.

\section{Findings}

Thanks to our longitudinal study, we were able to observe entrepreneurial network dynamics in action. The transcribed interviews and collected documents were analyzed using NVivo software, which provides visual outputs. We were able to create egocentric sociograms and to develop a network mapping of each entrepreneurial network. Based on these mappings, we first reproduced and then coded what ANT theorists call an "abridged script of a socio-technical path," which enabled us to move from a narrative description of the entrepreneurial projects to their sociotechnical records (Latour et al., 1992). 
We thus applied three ANT socio-technical indicators to enhance our reading of each entrepreneurial trajectory. Finally, we plotted the evolution of the entrepreneurial networks on a socio-technical graph to illustrate visually the dynamic evolution of these socio-technical indicators over time (Latour, 1991).

We present below the results of the study and interpret the socio-technical graph to explain the importance of materially heterogeneous entities during the complex start-up phase.

\section{Insert Table 4 Here}

\subsection{Case 1 SuperNova: Socio-technical path}

SB was a young entrepreneur aged 23 , and a soon-to-graduate student at a prestigious engineering school in France, specializing in mechanical engineering. He decided to start a business to build on one of his student projects. His business would offer companies a service validating electronic components in a simulated space flight in the extreme conditions of space. This validation service would be sold through two products developed by the entrepreneur: A Flymate and a nano-satellite that would be integrated into a rocket and sold to customers, such as research labs, universities, or start-ups.

The data showed that the entrepreneur was able to crystallize an entire, stable, socio-technical network, whose core consisted of the entrepreneurial team and the project. 
A close reading of the SuperNova trajectory reveals three significant phases in the entrepreneurial process ${ }^{6}$ during which artefacts played a significant role (Figure 2).

\section{Insert Figure 2 here}

Phase 1: Here the entrepreneurial network is resistant enough $(\mathrm{R}=1)$, but not profitable enough to ensure the continuity of the entrepreneurial process. The increasing IN reflects the growing need to review the venture to be able to enlist new actors.

This is further confirmed by the incubator advisor asking the entrepreneur to strengthen the technical aspect of his project by presenting a working prototype.

“We've got a project based on real facts, to help us prove that it's a project with real potential. We have to prove it technically, to avoid the day when people criticize us for our incompetence. We need a prototype that attests to a technology that works. Our partners have set ideas about the space domain. They think it's the reserve of big companies like NASA, ESA or EADS. All these prejudices pose enormous problems that force us to spend a lot of time and energy to convince people that we are capable of achieving this. Every time, we have proven our capacity by making a new improved version of the prototype that works and confirms the repeatability of the results. Thanks to that, we are changing their prejudices and convincing them to buy into our project." (SB)

Phase 2: The social profitability of the project has fallen by nearly $40 \%$ at this stage. The project is no longer able to mobilize most of the actors that have seen it. This poor social profitability has

\footnotetext{
${ }^{6}$ Important variations in terms of cadence of the network dynamic construction allowed us to outline the main phases (Figures 1, 2 and 3). The interpretation of the socio-technical indexes and their evolution over time, as well as our discussion with the three entrepreneurs, confirmed these phases.
} 
impacted the cohesiveness of the network and $\mathrm{R}$ has gone from 1 to 0.87 , due to delays in prototype development. This results in the dissociation of several actors and a need for the social renegotiation of the project. The entrepreneur then accelerates technological development to quickly remedy the situation, improve legitimacy, and put the entrepreneurial project back on track.

"People are against our project because they aren't convinced it's feasible. They say that they don't believe in it...it's those people from the technology transfer office who refused to help us. Their position resulted in delays in us carrying out our tasks. There were other people who were skeptical. We had a lot of difficulties because of the simple fact that the CNES (National Centre for Space Studies) refused to support us, so a lot of people were dismissive of our project. In my opinion, our project didn't get the support that it deserved from the technology transfer office right from the start, and now it's been totally abandoned." (SB)

"Once the concept is finalized, we'll develop a prototype next April. Then we'll go to India at the end of November, to negotiate with the Indians and perhaps in two months we'll have the results for our idea. Then we'll go see some Russian experts whom we are negotiating with and I think that's how we'll prove this works." (SB)

Phase 3: The entrepreneur has successfully translated his activities into two video recordings, which are sent to the key actors in his network. These videos contribute to restoring the cohesiveness of the network, and its social profitability is back on the increase. IN converges to zero, reflecting temporary entrepreneurial network stability.

"Over the past two months we saw [how], after we developed the Flymate, which is already operating and in an advanced stage, people have started to see us differently. It's amazing! 
There is no change in the project or the entrepreneurial team... just a little video that shows the technology is working and they look at us differently!" (SB)

\subsection{Case 2 Zebrafish: Socio-technical path}

The Zebrafish project relied on the use of the transgenic fish called Zebrafish or Danio rerio. Owing to its biological properties, this small freshwater fish is increasingly used in scientific research as a model organism. The aim of the entrepreneur, LS, was to use the scientific properties of this fish to develop candidate molecules for new drugs. The idea emerged from the desire to use the research findings of a French molecular zoology laboratory. The future firm would operate in the "screening" market. The 46-year-old entrepreneur had a $\mathrm{PhD}$ in industrial pharmacy and over 15 years' international experience in the commercialization of medical devices.

As Figure 3 illustrates, the entrepreneurial network process dynamics in the case of Zebrafish followed a disappointing trajectory. After the initial positive feedback at V2 and subsequently V3, the social profitability of the project began to decrease. The entrepreneurial network had almost completely dissolved by the last version (V6).

\section{Insert Figure 3 here}

Upon closer study, the graphs display strong distress signals following version 3 , highlighting the seriousness of the situation. However, the entrepreneur failed to react and remained inactive in his negotiations with the university and the Technology Transfer Office.

The right to exploit the transgenic fish developed in a university laboratory was at the center of negotiations and was also the cause of the project's stagnation. As with the case of the scallops in Saint Brieuc Bay (Callon, 1986), the entrepreneur and his team failed to connect the fish to their 
entrepreneurial project. Despite the team's certainty about the feasibility of the project, they did not succeed in turning the technology into a reality, as they failed to present a chain of genotypes of the transgenic fish larvae (F0, F1, F2, etc.), which would have allowed them to prove the maturity of the new technology and market the idea. This incapacity to develop a technological demonstrator (in the form of a chain of genotypes) caused the founder to abandon the venture six months prior to the completion of our study.

Phase 1: After a promising start to the entrepreneurial process with a socially profitable project, the situation deteriorated fast. While $\mathrm{R}$ and IN were encouraging, the project was not able to attach itself to the majority of the actors it mobilized.

Phase 2: IN moved from zero to 1, which attests to the loss of previous achievements. Due to both the complexity of the entrepreneurial situation and the betrayal of the transgenic Zebrafish, the nascent entrepreneur was unable to solve the problem. This put an end to the entrepreneurial dynamics and caused the disintegration of the entrepreneurial network during version 6 . Consequently, the entrepreneurial project was eventually stopped.

"The ideal context to develop my idea would be to show that there is a real entrepreneurial opportunity, a way in which I can assure that what has already been almost proven is really proven. I need the demonstration of the chain of genotypes F0, F1 and F2, in order to demonstrate its feasibility. This is the prerequisite, so we can really rely on a properly assessed, concrete intellectual property. We can then negotiate based on something tangible. At the moment, we are negotiating on abstract terms. We need something concrete to legitimize the firm. What is stalling me in my relations with my other partners today is the 
material and tangible value of the innovation. We started off with a certain level of success with this project and now we're blocked." (LS)

\subsection{Case 3 Reproxx: Socio-technical Path}

The founder of Reproxx (PP) was 45 and held degrees in veterinary medicine and management. After years of work experience in animal biotechnology in a large international firm, he engaged in the process of creating a new venture, Reproxx. The start-up, which was intended to operate in the veterinary sector, originated from the identification of a business opportunity in the agriculture sector. PP aimed to design a diagnostic tool for the identification of bovine gestation by measuring progesterone levels. The test works by detecting the presence of specific antibodies in the milk using immunochromatography. When we started our study, Reproxx had just joined a local French technology incubator, while simultaneously negotiating the conditions for the transfer of antibody ownership rights with a research laboratory.

Unlike the two other projects, the early stage of this social networking process was more cumbersome. Even though the PowerPoint slides and incubation agreement played an intermediary role in raising the interest of some actors, a key element in the project—-the antibodies—stalled the network's development (see Table 5). As soon as PP engaged in the entrepreneurial process, he encountered problems of information asymmetry with the laboratory supplying the antibodies. Indeed, it was always very difficult for him to obtain information about the antibodies that were at the heart of the project. Every time he asked about the availability and characteristics of the antibodies, he received unverified bits of information, which generated tensions early on in his relationship with the research unit. 
The attachment of the antibodies to the project proved to be a very complicated task. The negotiations with the laboratory about the conditions of the transfer of ownership rights to the antibodies took highly variable amounts of time. The final agreement was reached due to the creation of a scientific committee involving the entrepreneur, the laboratory, the National Breeders' Association, a private company and the Technology Transfer Office. The association-dissociation movement of the antibodies affected the cohesiveness of the entrepreneurial network, as shown in Figure 4.

\section{Insert Figure 4 Here}

"The university was opposed to the project to start with. But I did not give up, I negotiated, and finally, I managed to get them on board. I invited them to join the scientific committee for the project, which means they will experience the project from the inside, and this is important. Also, this scientific committee includes the lab that owns the antibodies, a researcher in reproduction physiology, the Breeders' Association (L'Union des Éleveurs), etc. " (PP)

Phase 1: At this stage, the project had to negotiate to mobilize the interest of the necessary actors. Due to the biological properties of milk and its changing and unstable matrix, the entrepreneur hesitated whether to develop the test for measuring progesterone concentration in milk or in blood. However, the project was socially profitable, in the sense that it could attach itself to the majority of the actors it mobilized.

"In my view, in order to succeed you need something concrete, something real, and the ability to coordinate all the members in the network to do their job well. When you don't yet have a 
product, there is no need to go and stir up the network. You need something to show them. If you have nothing to show it's just a waste of time." (PP)

Phase 2: The entrepreneurial network required the renegotiation of the project, which appeared through an increase in IN from 0.10 to 0.33 . The entrepreneur reacted positively to this demand by deciding to use blood rather than milk tests. This explains the increase in Y. However, the reality of the project remained variable because of the persistent confusion about the antibodies.

"I wanted to avoid a maximum of potential obstacles related to the antibodies properties, so I would rather work on blood than milk. Milk is more complicated. I would rather work on one difficulty at a time, split the problem, so instead of working on a very complicated concept, we are going to work on a more accessible method. We are going to use blood rather than milk tests, even though this approach is not totally devoid of risks." (PP)

Phase 3: In this last phase, the need for negotiation was fairly weak $(0.11<\mathrm{IN}<0.14)$ and the entrepreneurial network started to stabilize. However, social profitability was limited, with $\mathrm{Y}$ at around zero in the final version (V8). This result can be explained by the stabilization of the network that supported the newly created firm. The scientific committee set up by the entrepreneur played a significant role here.

In sum, our findings show that material artefacts play an important role in entrepreneurial network dynamics. Non-human objects, such as antibodies, transgenic fish larvae, or videos, impacted the trajectory of the three entrepreneurial networks, as shown by the socio-technical graphs. We reveal the importance of considering all acting entities as materially heterogeneous networks. Finally, our data show how including non-human objects in network analysis could provide an interesting perspective to further our understanding of the new venture creation process. 


\section{Discussion and theoretical implications}

The point of departure for this study was the lack of empirical research on the material/social networking dynamic in the context of start-up creation and how agents perform entrepreneurial outcomes. Indeed, few researchers have studied agential variation/dynamics in the context of new venture emergence (Jones et al., 2010), unlike the broader management and marketing literature (i.e. Hageberg \& Kjellberg, 2010; Doganova \& Karnøe, 2015).

By emphasizing the hybrid combination of the entrepreneur's networking process and how material heterogeneity might contribute to nascent entrepreneurship, this study contributes to knowledge and understanding in the following ways.

Our first conceptual starting point was to consider all acting entities (actants) as materially heterogeneous networks. Agents are always equipped, sometimes with human bodies and minds, along with other materials. We studied human and non-human actors simultaneously, and our findings clearly demonstrate how entrepreneurial outcomes cannot be explained with reference to the social sphere alone, as materiality also plays a part in shaping entrepreneurial performances (Jones et al., 2010). Therefore, the role of materiality should not be ignored when looking at entrepreneurial networks, since material artefacts are an essential part of the nascent entrepreneur's everyday activities.

Our data shows the role of materiality in the trajectory and the outcome of network dynamics for nascent entrepreneurs; this has hitherto been neglected. We also demonstrate how material artefacts can play a pivotal role in communicating difficult-to-grasp new concepts and innovations to an unconvinced public. 
In their conceptual paper, Jones et al. (2010) suggest research propositions related to material artefacts and their importance in knowledge "acquisition, absorption and application" but their assertion is not based on any empirical work. Our research empirically supports their assertion that material artefacts play an important role during the nascent entrepreneurial stage. We show how material artefacts objectify or embody collective knowledge and demonstrate the importance of object-centered social relations (such as the video for Supernova—people needed a concrete vision of the project). Our findings corroborate Jones et al.'s (2010) proposition that mediating objects can be an important means of enabling essential discussion and debate for nascent entrepreneurs with vision. For example, SB had vision but it took a video to demonstrate it visually to other entities. We also build on Jones et al.'s (2010) theorizing as we emphasize networks and consider interactions with a range of actors: human-non-human and inside-outside the start-up. Our study provides further insights into how hybrid networks assist in these interactions.

Using socio-technical graphs (Latour et al., 1992), we show that the agential configuration of an entrepreneurial network varies in terms of number of entities, duration of links and structure of association. The activity levels of entrepreneurial networks also vary, which may depend on the constitution/hybridity of their network. Socio-technical graphs allow us to map a network's evolution over time as a set of indexes and graphs. They help us to improve and simplify the readability of the constitution and variation of entrepreneurial networks. This approach has produced quantitative measures adapted to the contingent and circumstantial characteristics of each entrepreneurial situation.

By calculating the socio-technical indexes, we reveal the importance of considering the number of agents, the need for negotiation and revision of the entrepreneurial project, the durability of associations and how material artefacts associate and integrate with other entities. We provide 
important new insights into network theory in the entrepreneurial context by focusing on material artefacts, which have so far been an under-studied aspect of entrepreneurial networks.

We look at socio-material heterogeneity in entrepreneurial networks, seeing how and where nonhuman entities fit, in terms of network composition and configuration, as well as the purpose they serve, revealing temporal aspects to this purpose. For example, the timing of the interaction or manifestation of material artefacts in networks is crucial to understanding their subsequent impact on network cohesiveness and entrepreneurial outcomes. In the case of SuperNova, the index of reality decreased due to delays in prototype development; in the case of Zebrafish, the entrepreneurial network dispersed when the entrepreneur failed to present a chain of genotypes. In line with this, our findings reveal that hybrid entrepreneurial networks that feature material entities often ensure active and reactive start-up processes. The trajectory of the Reproxx sociographs reflects this reactivity, which can be explained by the antibodies' association/dissociation movement.

Our application of a symmetric approach to entrepreneurial network analysis clearly reveals the strategic roles that both human and non-human actors play in performing start-ups (Jones et al., 2010). Agents shaped the entrepreneurial trajectory of each project and deeply impacted the entrepreneurial outcomes. We found that collaboration, involving a variety of elements (researchers, entrepreneurs, business actors, prototypes, animals, etc.), represented a key factor in developing entrepreneurial networks. The collaborative agreement emerging from interactions between agents and their environments appears to earn the commitment, involvement and engagement of key actors (Nicolini et al., 2012). In this way, the heterogeneity of the network provides an infrastructure that triggers and sustains cross-disciplinary collaboration (Nicolini et al., 2012). For example, the strategic committee in the Reproxx case is composed of key entities who 
advise the entrepreneur-initially, these entities, such as the research lab, the National Breeders' Association, and a private company, acted against the project to serve their own interests. This committee created an artificial environment for common work, a strategic space that helped to reduce conflicts of interest between network members and provided a collaborative working base. Our three cases show how agents varied in terms of their configuration and conformity to entrepreneurial programs. The comparison of the resistance index $(\mathrm{R})$ in the three cases shows that an entrepreneurial network composed of more durable and stable links performs better than agents with a highly varied network structure. This tends to confirm the results of Hagberg and Kjellberg (2010: 1032), who wrote, "Unless the associations hold, the configuration will be unable to perform as an agent." We build on their findings by providing an indicator to measure the durability of links.

This study also highlights how entities are more (or less) useful at different stages of the entrepreneurial process. The case studies show the existence of other kinds of elements that have a smaller impact and are more time-limited. They adhere temporarily to accomplish a mission such as interessement (Callon, 1986; Akrich et al., 2002a) or to mobilize commitment (Nicolini et al., 2012). For example, when the video of the Flymat demonstration is mobilized it mediates the dialectic of resistance and accommodation in the SuperNova project.

Agents can act as "spokespersons" (Callon, 1986; Akrich et al., 2002b), reflecting the intentions, aspirations, meanings, functions and skills of entrepreneurial entities. They enable projections of future performance and outcomes. By assuming the role of mediator (Jones et al., 2010), the agent becomes a "communication vehicle" that reduces any potential misrepresentation and/or information asymmetry when interacting with others. In this, our study differs from previous works dealing with ANT by showing that agents' capacity to act programmatically includes their ability 
to help start-ups escape uncertainty and reduce information asymmetry. We show how agential configuration or the agential make-up of entrepreneurial networks can be instrumental and decisive in the exploration/exploitation of entrepreneurial opportunities. The agential configuration acts to cope with a series of entrepreneurial challenges and controversies, such as scarcity of resources, uncertainty, ambiguity or complexity (Hoholm \& Olsen, 2012), and their impact on the start-up's likely survival (Lamine et al., 2014). This was particularly pertinent in the case of SuperNova, where others perceived space technology innovations as the sole preserve of NASA or other big industry players. By physically and visually demonstrating his capabilities, the agent was able to mobilize external actants' belief in the program. We also believe that agents can maintain and sustain the entrepreneurial system (Bruyat \& Julien, 2001) ensuring coherence across intersecting social and material worlds (Star \& Greismer, 1989).

We found that the variation of agential configurations involves the progressive development and improvement of different versions of prototypes, business plans, business models and videos. Given the experimental nature of the entrepreneurial process, the emergence of different elements follows an iterative, trial-and-error, evolutionary path. To move from one configuration to another, agents develop new capabilities: knowledge, motives, functions, intentions, meanings and skills (Hagberg \& Kjellberg, 2010). These cumulative capabilities are mobilized in subsequent configurations throughout the learning by doing process, which translates into successive changes made to enrich the agential structure (i.e. new business models, new videos, enhancements of prototypes, new consultants, and improvements to the business plan). These capabilities enable the agent to provide alternatives for entities that do not convert (Hagberg \& Kjellberg, 2010). In the Reproxx case, a corresponding example is how to deal with the biological properties of milk and its changing matrix. The alternative was, after a series of scientific experimentations, to use a blood 
rather than milk test. Another example is SuperNova's incremental development of the Flymate prototype series. Thus, we suggest that start-up performance is related to agential change or the reflexive capacity (Andersson et al., 2008) to learn from previous experiences and make adjustments on that basis (Hagberg \& Kjellberg, 2010). This reflexivity around the co-construction of entrepreneurial projects becomes a structuring force in the hybrid entrepreneurial network, which in turn strengthens the coherence of the entrepreneurial system (Bruyat \& Julien, 2001). Consequently, this increases the ability of the project to recruit and mobilize elements that will feed it with vital resources and skills (Hoholm \& Olsen, 2012). The Yield index (Y), which measures the capacity of a project to attach itself to the majority of the actors it mobilizes (Latour et al., 1992), can be used here as an indicator to measure the agential capacity to enroll new entities providing valuable resources and skills and so perform a start-up.

Finally, although agents may act programmatically, there is a note of caution here. Through intentional or involuntary behavior, agents can potentially betray the entrepreneur (Law, 1997). As mentioned above, agential capabilities may perform entrepreneurial outcomes (as in the case of SuperNova) but they may also act as stumbling blocks/obstacles when they are not aligned with the nascent entrepreneur's plan of action.

Akrich and Latour (1992) used the program and anti-program dichotomy to characterize acts as in conflict (or not) with prescribed behavior. In the conceptual classification proposed by Helgesson and Kjellberg (2005), the authors argued that this distinction between programmatic and antiprogrammatic behavior hides a variation that is important for our understanding of the relations between entities. They also noted that the behavior of an associated element can be neither programmatic nor anti-programmatic but simply "not programmatic." They suggested that a 
distinction should be made between compliant and non-compliant, aligned and non-aligned behavior. Our case studies contribute to this discussion in the specific entrepreneurship context. In particular we show empirically that successful configuration of entrepreneurial networks rests on non-human entities having been perfectly aligned and compliant with the nascent entrepreneur's vision. SuperNova's video of Flymat shows the technology is working; the feasibility of Reproxx is confirmed by the enrolment of antibodies. Conversely, our analysis shows that non-human entities can have non-programmatic or non-aligned compliant behavior. For example, PP said, “At the moment the Breeders' Association is an ally, but we have two very different visions. Its objective is not to sell the product, but to help breeders. My aim is to sell; we don't have the same goals." Entities can also adopt anti-programmatic behavior (e.g. the chain of genotypes of the transgenic fish larvae that refused to "join" the Zebrafish project).

The point we want to stress is that humans are not heroes who control the entrepreneurial path. Our study shows that the heterogeneity of an entrepreneurial network can play a beneficial role for the start-up, while it can also create obstacles and generate controversies, misunderstandings and tensions.

\section{Conclusion}

This study has indicated that to expand our understanding of entrepreneurs' network dynamics we need to address more precisely the role of materially heterogeneous entities during the start-up phase. Our research is one of the first empirical studies of the social/material network dynamic in nascent entrepreneurship. It reveals how the heterogeneity of agents is critical for start-ups. Our aim was to investigate the impact of materially heterogeneous entities on the networking process and how this might contribute to nascent entrepreneurship. Our analysis shows the intricate dance 
of entrepreneur, material artefacts, and stakeholders in the new venture creation context. Viewing this process through an entrepreneuring lens, we applied ANT (Callon, 1986; Latour, 1987, 1991) to the issue and contributed some answers to our central question: "What are the roles of materially heterogeneous entities during the networking start-up phase?" The symmetric view of human and non-human actors (Latour, 1987) enables us to move away from the figure of the heroic entrepreneurial actor, a welcome sea change in entrepreneurship research. While the non-human entity needs somebody to move it and make things happen, entrepreneurs are limited in the ways in which they can control how others perceive/react to the actant (and cannot always control what the actant does, e.g. Zebrafish). Our findings reveal the varied roles that actor-network heterogeneity can play in the start-up process. We see its power of attraction to recruit new allies that are aligned and compliant with the entrepreneur's vision as well as its potential to perform. In contrast, they may also betray the entrepreneur due to their repellent force, that is, their ability to block the new venture creation process. They can demonstrate non-programmatic and antiprogrammatic behaviors (Helgesson \& Kjellberg, 2005), for example, when they fail to translate what the entrepreneur has in mind. Our contributions support the emerging literature of social and material aspects in management research (Ridder, Hoon \& Baluch, 2012) in suggesting the “inherent inseparability" of social and material aspects of entrepreneuring processes (Orlikowski, 2008; Jones et al., 2010). Moreover, our research suggests that heterogeneous networks may provide a sound basis for an infrastructure that triggers and sustains cross-disciplinary collaboration and that we recommend more research is carried out in this vein to further prove (or disprove) this claim.

We have grounded our analyses and theory building in the context of start-ups and nascent entrepreneurship. This might limit the empirical contributions of our observations to this context. 
Our longitudinal case study of three projects may suffer from peculiarities that remain untested in wider contexts. However, despite these limitations, our results have methodological implications. Research-based case studies focusing on social networks have been criticized for their fragmented or piecemeal approach to network analysis (Latour, 1989). The use of socio-technical graphs serves two important functions that allow us to avoid such shortcomings. First, the graphs enable us to assess quantitatively the socio-technical network capacities in each entrepreneurial project and consider the network's variation over time in response to the changing nature and circumstantial context of the start-up. Second, they enable us to compare different network dynamics across multiple cases of venture creation.

In terms of managerial implications, this study shows the relevance of material artefacts and the need for entrepreneurs to realize the significance of their role. Material artefacts are an important communication tool, critical for projecting ideas and an entrepreneur's vision to relevant audiences. It is therefore critical that those engaged with the type of activities reported here become aware of their relevance. Broadening understanding might be achieved through working with advisors, trainers and others who support the incubation process to extend understanding.

In closing, this study illuminates the importance of materiality and contributes to opening the avenue of materially heterogenous network research in the entrepreneurship field. Future research could use these tools in other contexts and at different stages of the entrepreneurial process. Finally, we call for future research that will go beyond stating that materiality is important and which looks to explore the mechanisms, preconditions and dynamics through which translation, resistance and the collapse of entrepreneurial networks happen. 


\section{REFERENCES}

Aaboen, L., Dubois, A., \& Lind, F. (2013). Strategizing as networking for new ventures. Industrial Marketing Management, 42(7), 1033-1041.

Akrich, M. (1992). The de-scription of technical objects. In W. E. Bijker \& J. Law (Eds.), Shaping Technology/Building Society (pp. 205-224). Cambridge, MA: MIT Press.

Akrich, M., Callon, M., \& Latour, B. (2002a). The key to success in innovation part I: The art of interessement. International Journal of Innovation Management, 6(2), 187-206.

Akrich, M., Callon, M., \& Latour, B. (2002b). The key to success in innovation part II: The art of choosing good spokespersons. International Journal of Innovation Management, 6(2), 207225 .

Andersson, P., Aspenberg, K., \& Kjellberg, H. (2008). The configuration of actors in market practice. Marketing Theory, 8(1), 67-90.

Araujo, L. (2007). Markets, market making and marketing. Marketing Theory, 7(3), 211-226.

Araujo, L., \& Kjellberg, H. (2009). Shaping exchanges, performing markets: The study of marketing practices. In P. Maclaran, M. Saren, B. Stern, \& M. Tadajewski (Eds.), Handbook of marketing theory (pp. 195-218). London: Sage.

Araujo, L., Kjellberg, H., \& Spencer, R. (2008). Market practices and forms: Introduction to the special issue. Marketing Theory, 8(1), 5-14.

Azimont, F., \& Araujo, L. (2007). Category reviews as market-shaping events. Industrial Marketing Management, 36(7), 849-860.

Azimont, F., \& Araujo, L. (2010). The making of a petrol station and the "on-the-move consumer": Classification devices and the shaping of markets. Industrial Marketing 
Management, 39(6), 1010-1018.

Baron, R. A., \& Markman, G. D. (2003). Beyond social capital: the role of entrepreneurs' social competence in their financial success. Journal of Business Venturing, 18, 41-60.

Baron, R. A., \& Tang, J. (2009). Entrepreneurs' social skills and new venture performance: Mediating mechanisms and cultural generality. Journal of Management, 35(2), 282-302.

Bøllingtoft, A., \& Ulhøi, J. (2005). The networked business incubator: Leveraging entrepreneurial agency? Journal of Business Venturing, 20 (2), 265-290.

Brand, M., Croonen, E. \& Leenders, R. (2012). Knowledge acquisition through strategic networks: the case of franchising. In F. Welter, D. Smallbone, \& A. Van Gils, (Eds.), Entrepreneurial processes in a changing economy: frontiers in European entrepreneurship research, pp. 110-138. Cheltenham: Edward Elgar.

Brüderl, J., \& Preisendörfer, P. (1998). Network support and the success of newly founded businesses. Small Business Economics, 10, 213-225.

Bruyat, C., \& Julien, P. A. (2001). Defining the field of research in entrepreneurship. Journal of Business Venturing, 16(2), 165-180.

Callon, M. (1986). The sociology of an actor-network: The case of the electric vehicle. In M. Callon, J. Law, \& A. Rip (Eds.), Mapping the dynamics of science and technology: Sociology of science in the real world, pp. 19-34. London: Macmillan.

Callon, M., \& Law, J. (1995). Agency and the hybrid collectif. The South Atlantic Quarterly, 94(2), $481-507$.

Clarke, J. (2011). Revitalizing entrepreneurship: How visual symbols are used in entrepreneurial performances. Journal of Management Studies, 48(6), 1365-1391.

Davidsson, P., \& Honig, B. (2003). The role of social and human capital among nascent entrepreneurs. Journal of Business Venturing, 18(3), 301-331. 
Doganova L., \& Karnoe P. (2015). Building markets for clean technologies: Controversies, environmental concerns and economic worth. Industrial Marketing Management, 44, 22-31.

Doganova, L., \& Eyquem-Renault, M. (2009). What do business models do? Innovation devices in technology entrepreneurship. Research Policy, 38, 1559-1570.

Dubois, A., \& Araujo, L. (2004). Research methods in industrial marketing studies. In H. Håkansson, D. Harrison, \& A. Waluszewski (Eds.), Rethinking marketing: Developing a new understanding of markets, pp. 207-227. Chichester: Wiley.

Dubois, A., \& Gadde, L.-E. (2002). Systematic combining: An abductive approach to case research. Journal of Business Research, 55, 553-560.

Dubois, A., \& Gadde, L.-E. (2014). “Systematic combining”-A decade later. Journal of Business Research, 67, 1277-1284.

Elfring, T., \& Hulsink, W. (2003). Networks in entrepreneurship: The case of high-technology firms. Small Business Economics, 21, 409-422.

Engeström, Y. (1990). Learning, working and imagining: Twelve studies in activity theory. Helsinki: Orienta-Konsultit Oy.

Gartner, W. B., \& Birley, S. (2002). Introduction to the special issue on qualitative methods in entrepreneurship research. Journal of Business Venturing, 17(5), 387-395.

Hagberg, J., \& Kjellberg, H. (2010). Who performs marketing? Dimensions of agential variation in market practice. Industrial Marketing Management, 39(6), 1028-1037.

Harrison, D., \& Kjellberg, H. (2010). Segmenting a market in the making: Industrial market segmentation as construction. Industrial Marketing Management, 39(5), 784-792.

Harrisson, D., \& Laberge, M. (2002). Innovation, identities and resistance: The social construction of an innovation network. Journal of Management Studies, 39(4), 497-521. 
Helgesson, C.-F., \& Kjellberg, H. (2005). Macro-actors and the sounds of the silenced. In B. Czarniawska \& T. Hernes (Eds.), Actor-network theory and organizing. Malmö, Sweden: Liber/ CBS.

Hernes, T. (2007). Understanding organization as process: Theory for a tangled world. London: Routledge.

Hitt, M. A., Duanne Ireland, R., Sirmon, D. G., \& Trahms, C. A. (2011). Strategic entrepreneurship: Creating value for individuals, organizations and society. Academy of Management Perspectives, 25, 57-75.

Hoang H., \& Antoncic, B. (2003). Network-based research in entrepreneurship. A critical review. Journal of Business Venturing, 18(2), 165-187.

Hoholm, T., \& Olsen, P. I. (2012). The contrary forces of innovation: A conceptual model for studying networked innovation processes. Industrial Marketing Management, 41, 344-356.

Honig, B., Davidsson, P., \& Karlsson, T. (2005). Learning strategies of nascent entrepreneurs. Journal of Competence-based Management, 1(3), 67-88.

Jack, S., Moult, S., Anderson, A., \& Dodd, S. (2010). An entrepreneurial network evolving: Patterns of change. International Small Business Journal, 28(4), 315-337.

Johannisson, B. (2011). Towards a practice theory of entrepreneuring. Small Business Economics, $36,135-150$.

Jones, O., Macpherson, A. \& Thorpe, R. (2010). Learning in owner-managed small firms: Mediating artefacts and strategic space. Entrepreneurship and Regional Development, 22(7), 649-673.

Karatas-Ozkan, M., \& Chell, E. (2010). Nascent entrepreneurship and learning. Cheltenham: Edward Elgar.

Kjellberg, H., \& Helgesson, C.-F. (2007). On the nature of markets and their practices. Marketing Theory, 7(2), 137-162. 
Laet, M., \& Mol, A. (2000). The Zimbabwe bush pump: Mechanics of a fluid technology. Social Studies of Science, 30(5), 225-263.

Lamine, W., Fayolle, A., \& Chebbi, H. (2016). Actor-network theory and the entrepreneurial process. In Fayolle, A. et al. (Eds.), Entrepreneurial process and social networks: A dynamic perspective. Cheltenham: Edward Elgar.

Lamine, W., Jack, S., Fayolle, A., \& Chabaud, D. (2015). One step beyond? Towards a process view of social networks in entrepreneurship. Entrepreneurship \& Regional Development, 27, 7-8, 413-429, DOI: 10.1080/08985626.2015.1070535

La Rocca, A., Ford, D., \& Snehota, I. (2013). Initial relationship development in new business ventures. Industrial Marketing Management, 42(7), 1025-1032.

La Rocca, A., Hoholma, T., \& Mørket, B. E. (2016). Practice theory and the study of interaction in business relationships. Industrial Marketing Management (in press).

Latour, B. (1987). Science in action: How to follow scientists and engineers through society. Cambridge: Harvard University Press.

Latour, B. (1991). Technology is society made durable. In J. Law, (Ed.), A sociology of monsters. Essays on power, technology and domination, pp. 103-131. Routledge, London.

Latour, B. (1992). Where are the missing masses? Sociology of a few mundane artefacts. In W. Bijker \& J. Law (Eds.), Shaping technology, building society: Studies in socio-technical change, pp. 225-258. Cambridge: MIT Press.

Latour, B (1994). On technical mediation. Common Knowledge 3 (2):29-64.

Latour, B., Mauguin, P. \& Teil, G., (1992). A note on socio-technical graphs. Social Studies of Science, 22(1), 33-57.

Law, J. (1986). On power and its tactics: A view from the sociology of science. The Sociological Review, 34(1), 1-39. 
Law, J. (1997), Traduction/trahison: Notes on Actor-Network Theory, TMV Working Paper Number 106, University of Oslo.

Lawlor, J., \& Kavanagh, D. (2015). Infighting and fitting in: Following innovation in the stent actornetwork. Industrial Marketing Management, 44, 32-41.

Lee, C., Lee, K,. \& Pennings, J. M. (2001). Internal capabilities, external networks, and performance: A study of technology-based ventures. Strategic Management Journal, 22, 615-640.

Mosey, S., \& Wright, M. (2007). From human capital to social capital: A longitudinal study of technology-based academic entrepreneurs. Entrepreneurship Theory \& Practice, 31(6), 909935.

Nicolini, D. (2010) Medical innovation as a process of translation: A case from the field of telemedicine. British Journal of Management, 21(4), 1011-1026.

Nicolini, D., Mengis, J., \& Swan, J. (2012) Understanding the role of objects in multidisciplinary collaboration. Organization Science, 23, 612-629.

O'Donnell, A., Gilmore A., Cummins D. \& Carson D. (2001). The network construct in entrepreneurship research: A review and critique. Management Decision, 39(9), 749-760.

Okhuysen, G., \& Bechky, B. (2009). Coordination in organizations: An integrative perspective. The Academy of Management Annals, 3(1), 463-502.

Orlikowski, W. J. (2007), Sociomaterial practices: Exploring technology at work. Organization Studies, 28(9), 1435-1448.

Orlikowski, W. J., \& Scott, S. V. (2008). Sociomateriality: Challenging the separation of technology, work and organization. The Academy of Management Annals, 2(1), 433-474.

Pettigrew, A. M. (1992). The character and significance of strategy process research. Strategic Management Journal, 3, 5-16. 
Reynolds, P. (1997). Who starts firms? Preliminary explorations of firms in gestation. Small Business Economics, 9, 449-462.

Ridder, H. G., Hoon, C., \& Baluch, A. M. (2012). Entering a dialogue: Positioning case study findings towards theory. British Journal of Management, 21(4), doi: 10.1111/14678551.12000.

Sandberg, J., \& Tsoukas, H. (2011). Grasping the logic of practice: Theorizing through practical rationality. Academy of Management Review, 36(2), 338-360.

Shove, E., \& Araujo, L. (2010). Consumption, materiality and markets. In L. Araujo, J. Finch, \& H. Kjellberg (Eds.), Reconnecting marketing to markets. Oxford: Oxford University Press.

Shove, E., \& Pantzar, M. (2005). Consumers, producers and practices: Understanding the invention and reinvention of Nordic walking. Journal of Consumer Culture, 5(1), 43-64.

Snijders, T. A. B, van de Bunt, G. G., \& Steglichc, C. (2010) Introduction to stochastic actor-based models for network dynamics. Social Networks, 32, 44-60.

Stake, R. E. (2003). Case studies. In N. K. Denzin \& Y. S. Lincoln (Eds.), Strategies of qualitative inquiry (2nd ed.). London: Sage, 443-466.

Stam, W., Arzlanian, S., \& Elfring, T. (2014). Social capital of entrepreneurs and small firm performance: A meta-analysis of contextual and methodological moderators. Journal of Business Venturing, 29 (1), 152-173.

Star, S. L., \& Greisemer, J. R. (1989). Institutional ecology, "translations" and boundary objects: Amateurs and professionals in Berkely’s Museum of Vertebrate Zoology’. Social Studies of Science, 19(3), 387-420.

Steier, L., \& Greenwood, R. (2000). Entrepreneurship and the evolution of angel financial networks. Organization Studies, 21(1), 163-193. 
Steyaert, C. (2007). Entrepreneuring as a conceptual attractor? A review of process theories in 20 years of entrepreneurship studies. Entrepreneurship and Regional Development, 19(2), 453477.

Suchman, L.A. (2007). Human-machine reconfigurations: Plans and situated actions. New York: Cambridge University Press.

Tello, S., Yang, Y., \& Latham, S. (2012). Nascent entrepreneurs' access and use of network resources in a technology incubator. Journal of Small Business \& Entrepreneurship, 25(3), $375-397$.

Westhead, P., \& Wright, M. (2011). David Storey's optimism and chance perspective: a case of the Emperor's new clothes? International Small Business Journal, 29, 714-729.

Yin, R. K. (2003). Case study research: Design and methods (3rd ed.). Thousand Oaks: Sage. 
Table 1 Selected empirical business studies inspired by ANT-oriented perspectives

\begin{tabular}{|c|c|c|c|}
\hline Title & Authors & Research question/Topic & Main contributions \\
\hline $\begin{array}{l}\text { Building markets for clean } \\
\text { technologies: Controversies, } \\
\text { environmental concerns and } \\
\text { economic worth }\end{array}$ & $\begin{array}{l}\text { Doganova \& Karnøe } \\
(2015)\end{array}$ & $\begin{array}{l}\text { How goods are made both } \\
\text { environmentally and economically } \\
\text { valuable in the new market for clean } \\
\text { technologies that emerged in the } \\
\text { wake of the IPPC directive }\end{array}$ & $\begin{array}{l}\text { The market innovation process hinges on the composition of a complex network of actors } \\
\text { with divergent (and sometimes conflicting) interests. } \\
\text { The pivotal/performative role of a market device. }\end{array}$ \\
\hline $\begin{array}{l}\text { Infighting and fitting in: } \\
\text { Following innovation in the } \\
\text { stent actor-network }\end{array}$ & $\begin{array}{l}\text { Lawlor \& Kavanagh } \\
\text { (2015) }\end{array}$ & $\begin{array}{l}\text { This research reports on a study of } \\
\text { technological and market innovation } \\
\text { in the particular setting of new } \\
\text { market emergence }\end{array}$ & $\begin{array}{l}\text { - Confrontation ("violence") and antagonism are much more explicit and intense between } \\
\text { actors within an emergent network, and are conspicuous by their absence from the } \\
\text { relationships between emergent and established actors. } \\
\text { - Actors that enter the emerging market can anticipate being "destroyed" more quickly } \\
\text { and comprehensively than established actors. }\end{array}$ \\
\hline $\begin{array}{l}\text { Studying innovation } \\
\text { processes in real time: The } \\
\text { promises and challenges of } \\
\text { ethnography }\end{array}$ & $\begin{array}{l}\text { Hoholm \& Araujo } \\
(2011)\end{array}$ & $\begin{array}{l}\text { How can a real-time ethnography } \\
\text { help us theorize innovation } \\
\text { processes? }\end{array}$ & $\begin{array}{l}\text { Agential moments are revealed as the capacity to "contextualize interpretations of the past } \\
\text { and future projects." } \\
\text { Real-time ethnography can also shed light on how contexts of action are interpreted and } \\
\text { constructed by situated actors as much as the choices they face. } \\
\text { Controversies, tensions and fissures are provoked by the existence of alternative choice } \\
\text { paths; various political processes are involved in selecting and discarding options. }\end{array}$ \\
\hline 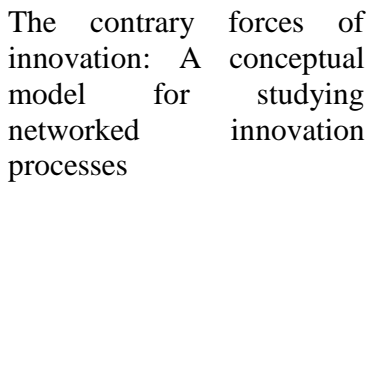 & $\begin{array}{l}\text { Hoholm \& Olsen } \\
(2012)\end{array}$ & $\begin{array}{l}\text { - How do interactive innovation } \\
\text { processes evolve over time? } \\
\text { - How is knowledge translated, } \\
\text { transformed and combined in } \\
\text { processes of innovation? } \\
\text { - What are the contrary forces } \\
\text { (frictions) of innovation processes? }\end{array}$ & $\begin{array}{l}\text { Actor-networks are recruited and committed to things with which they are initially } \\
\text { unfamiliar: An idea, a prospect or a prototype of something that may or may not become } \\
\text { feasible and usable. A degree of certainty has to be presumed. } \\
\text { The process of generating knowledge tends to multiply the alternatives of the object, and } \\
\text { hence increase the uncertainty/complexity-or development risk-of the project. } \\
\text { The innovation outcomes are never given "by the order of things," but instead are the } \\
\text { result of a series of negotiations and knowledge explorations over time. } \\
\text { Innovators have to 1) gather a chain of arguments suited for convincing, mobilizing, } \\
\text { maintaining and removing parts of actor-networks and their resources; 2) produce } \\
\text { testable propositions about reality. }\end{array}$ \\
\hline $\begin{array}{l}\text { Who performs marketing? } \\
\text { Dimensions of agential } \\
\text { variation in market practice }\end{array}$ & $\begin{array}{l}\text { Hagberg \& Kjellberg } \\
(2010)\end{array}$ & $\begin{array}{l}\text { How can we characterize those who } \\
\text { perform marketing? }\end{array}$ & $\begin{array}{l}\text { Identification of general dimensions of agential variation in three areas: the constitution } \\
\text { of agents, their programs of actions, their capacities. }\end{array}$ \\
\hline $\begin{array}{l}\text { The configuration of actors } \\
\text { in market practice }\end{array}$ & $\begin{array}{l}\text { Andersson, } \\
\text { Aspenberg \& } \\
\text { Kjellberg (2008) }\end{array}$ & $\begin{array}{l}\text { How can we conceptualize the } \\
\text { configuration of actors as part of a } \\
\text { practice approach to markets? }\end{array}$ & $\begin{array}{l}\text { Propose a vocabulary for addressing the composite nature of market actors, conceived as } \\
\text { configurations of multiple "actants." This allows us to 1) address the degree of overlaps } \\
\text { between actors across situations and the consequences of such overlaps; 2) address how it } \\
\text { becomes possible for actors to reflect on situations in which they find themselves; 3) } \\
\text { capture the rich repertoire of actor configurations that is possible in markets. }\end{array}$ \\
\hline
\end{tabular}




\section{Table 2 Summary of the methodological approach}

\begin{tabular}{|c|c|c|c|c|}
\hline \multicolumn{5}{|c|}{ Case 1: SuperNova (foundedOctober 2009) } \\
\hline Data collection & $\begin{array}{l}\text { - } 2 \text { interviews with } \\
\text { incubator manager } \\
\text { - } 4 \text { interviews with } \\
\text { the business adviser } \\
\text { helping the } \\
\text { entrepreneur }\end{array}$ & $\begin{array}{l}\text { - } 10 \text { interviews } \\
\text { with the } \\
\text { entrepreneur }\end{array}$ & $\begin{array}{c}\text { Participatory } \\
\text { observation (since } \\
\text { March 2008) }\end{array}$ & Additional documents \\
\hline Date & $\begin{array}{l}\text { September 2007- } \\
\text { October } 2010\end{array}$ & $\begin{array}{l}\text { March 2008- } \\
\text { October } 2011\end{array}$ & $\begin{array}{l}\text { - Visit to the } \\
\text { research laboratory } \\
\text { - Participation in } \\
\text { assessment meetings } \\
\text { within the incubator } \\
\text { - Participation in } \\
\text { the team meeting } \\
\text { and prototyping test } \\
\text { - Visit to the } \\
\text { science park }\end{array}$ & $\begin{array}{l}\text { Different versions of } \\
\text { business plan } \\
\text { Presentations } \\
\text { Application for the } \\
\text { OSEO competition } \\
\text { Videos of the } \\
\text { experiments } \\
\text { Different versions of } \\
\text { prototypes }\end{array}$ \\
\hline Duration & $6 \mathrm{~h} 30$ minutes & $20 \mathrm{~h} 20$ minutes & & \\
\hline \multicolumn{5}{|c|}{ Case 2: Zebrafish (termination of activity February 2010) } \\
\hline & $\begin{array}{c}2 \text { interviews with } \\
\text { incubator manager } \\
3 \text { interviews with } \\
\text { the business adviser } \\
\text { helping the } \\
\text { entrepreneur }\end{array}$ & $\begin{array}{l}6 \text { interviews with } \\
\text { the entrepreneur }\end{array}$ & $\begin{array}{l}\text { - Visit to the } \\
\text { research laboratory } \\
\text { - Participation in } \\
\text { assessment meetings } \\
\text { within the incubator } \\
\text { - Visit to the } \\
\text { science park }\end{array}$ & $\begin{array}{l}\text { - Different versions of } \\
\text { business plan. } \\
\text { - Presentations } \\
\text { - Application for the } \\
\text { OSEO competition } \\
\text { - Videos of the fish } \\
\text { experiments } \\
\text { - Different versions of } \\
\text { prototypes }\end{array}$ \\
\hline Date & $\begin{array}{c}\text { September 2007- } \\
\text { October } 2010\end{array}$ & $\begin{array}{c}\text { March 2008- } \\
\text { March } 2010 \\
\end{array}$ & & \\
\hline Duration & $5 \mathrm{~h}$ & $11 \mathrm{~h} 35$ minutes & & \\
\hline \multicolumn{5}{|c|}{ Case 3: Reproxx (founded January 2010) } \\
\hline Data collection & $\begin{array}{c}2 \text { interviews with } \\
\text { incubator manager } \\
3 \text { interviews with } \\
\text { the business adviser } \\
\text { helping the } \\
\text { entrepreneur }\end{array}$ & $\begin{array}{l}7 \text { interviews with } \\
\text { the entrepreneur }\end{array}$ & $\begin{array}{l}\text { - Visit to the } \\
\text { research laboratory } \\
\text { - Participation in } \\
\text { assessment meetings } \\
\text { within the incubator }\end{array}$ & $\begin{array}{l}\text { - Different versions of } \\
\text { business plan. } \\
\text { - Presentations } \\
\text { - Application for the } \\
\text { OSEO competition } \\
\text { - Different versions of } \\
\text { prototypes } \\
\text { - Different reports on } \\
\text { milk and blood analyses }\end{array}$ \\
\hline Date & $\begin{array}{c}\text { September } 2007- \\
\text { October } 2010 \\
\end{array}$ & $\begin{array}{c}\text { March 2008- } \\
\text { November } 2010\end{array}$ & & \\
\hline Duration & $5 \mathrm{~h}$ & $13 \mathrm{~h} 15$ minutes & & \\
\hline
\end{tabular}


Table 3 Abridged script of a socio-technical path

\begin{tabular}{|c|c|c|}
\hline \multicolumn{3}{|r|}{ Case 1: SuperNova } \\
\hline Version & $\begin{array}{l}\text { Network } \\
\text { Size }\end{array}$ & Network structure \\
\hline 1 & 1 & SB \\
\hline 2 & 2 & SB/Statement 1 \\
\hline 3 & 3 & SB/ST/ Statement 1/ \\
\hline 4 & 9 & SB/ST/ Statement 1/Professor/Lab. 1/ Lab. 2/ Incubator/ Presentation PPT1/ Business Model 1/ \\
\hline 5 & 18 & $\begin{array}{l}\text { SB/ST/ Statement 1/Professor/Lab. 1/Lab. 2/ Incubator/Firm AE/Firm EB/ Firm EF/ Firm EG/Prototype version1/Presentation } \\
\text { PPT2/Expert 1ESA/ Expert2ESA/ Expert1 CNES/ Expert1 Germany/Business Model 2/ }\end{array}$ \\
\hline 6 & 31 & $\begin{array}{l}\text { SB/ST/ Statement 1/Professor/Lab. 1/ Lab. 2/ Incubator/Firm AE/Firm EB/ Firm EF/ Firm EG/Prototype version1/Presentation } \\
\text { PPT2/Expert 1ESA/ Expert2ESA/ Expert1 CNES/ Expert2 CNES/ Expert1 Germany/Business Model 2/Statement 2/ExpertE } \\
\text { Russia/ German Lab./ Market study 1/ Prototype Version 2/ Firm GE/Programmer/ Incubation agreement / University } \\
\text { agreement/ Business plan 1/le Regional Council/ CNES/Mentor/ Prototype Version3/ }\end{array}$ \\
\hline 7 & 32 & $\begin{array}{l}\text { SB/ST/ Statement 1/Professor/Lab. 1/ Lab. 2/ Incubator/Firm AE/Firm EB/ Firm EF/ Firm EG/Prototype version1/Presentation } \\
\text { PPT2/Expert 1ESA/ Expert2ESA/ Expert1 CNES/ Expert2 CNES/ Expert1 Germany/Business Model 2/Statement 2/ExpertE } \\
\text { Russia/ German Lab./ Market study 1/ Firm GE/Programmer/Incubation agreement / University agreement/ Business plan } \\
\text { 1/le Regional Council/ CNES/Mentor/Prototype Version3/ Video/ Patent/ }\end{array}$ \\
\hline 8 & 48 & $\begin{array}{l}\text { SB/ST/ Statement 1/Professor/Lab. 1/ Lab. 2/ Incubator/Firm AE/Firm EB/ Firm EF/ Firm EG/Prototype version1/Presentation } \\
\text { PPT2/Expert 1ESA/ Expert2ESA/ Expert1 CNES/ Expert2 CNES/ Expert1 Germany/Business Model 2/Statement 2/ExpertE } \\
\text { Russia/ German Lab./ Market study 1/ Firm GE/Programmer/ Incubation agreement / University agreement/ Business plan } \\
\text { 1/le Regional Council/ CNES/Mentor/Prototype Version3/ Patent/ CNES scientist/3 } 3^{\text {rd }} \text { partner/Video 2/Students/Engineers/ } \\
\text { Regional Delegate of research / Ministry of Interior / RG / Ministry of Economy/ Firm YE/ ESTEC Network/ Electronic Expert } \\
\text { / Financial Advisor/ International Rocket Launcher/ }\end{array}$ \\
\hline 9 & 67 & $\begin{array}{l}\text { SB/ST/Statement 1/Professor/Lab. 1/Lab. 2/ Incubator/Firm AE/Firm EB/ Firm EF/ Firm EG/Prototype version1/Presentation } \\
\text { PPT2/Expert 1ESA/ Expert2ESA/ Expert1 CNES/ Expert2 CNES/ Expert1 Germany/ExpertE Russia/ German Lab./ Market } \\
\text { study 1/ Firm GE/Programmer/ Incubation agreement / University agreement/le Regional Council/ CNES/Mentor/Prototype } \\
\text { Version3/ Patent/ CNES scientist/3rd partner/Video 2/Students/Engineers/ Regional Delegate of research / Ministry of Interior } \\
\text { / RG / Ministry of Economy/ Firm YE/ ESTEC Network/ Electronic Expert / Financial Advisor/ International Rocket Launcher/ } \\
\text { Indian University/Emp/ Lab R1/Lab R2/ LEU/ International firm/ ONERA/LESIA/European University/ Association S/ OSEO/ } \\
\text { Application to OSEO program/ Bank/ European Investment Fund/ Business Angel/ Réseau entreprendre/ Chamber of } \\
\text { Commerce/NOVACITE/DGA/TTU/Statement 3/Prototype Version 4/ Business Model 3/ Business Plan 2/ Statues of the } \\
\text { new venture/ End }\end{array}$ \\
\hline \multicolumn{3}{|r|}{ Case 2: Zebrafish } \\
\hline Version & $\begin{array}{l}\text { Network } \\
\text { Size }\end{array}$ & Network structure \\
\hline 1 & 5 & $\mathrm{LS} / \mathrm{AB} / \mathrm{AC} / \mathrm{AD} / \mathrm{AE}$ \\
\hline 2 & 12 & LS/AB/AC/AD/AE /Lab UCB/University/CNRS/INRA/ENS/ EZUS/LST/ \\
\hline 3 & 16 & $\begin{array}{l}\mathrm{LS} / \mathrm{AB} / \mathrm{AC} / \mathrm{AD} / \mathrm{AE} \text { /Lab UCB/University/CNRS/INRA/ENS/EZUS/LST/Market Study /Alcimed/Incubator/ Incubation } \\
\text { agreement }\end{array}$ \\
\hline 4 & 17 & $\begin{array}{l}\mathrm{LS} / \mathrm{AB} / \mathrm{AC} / \mathrm{AD} / \mathrm{AE} / \mathrm{Lab} \mathrm{UCB} / \text { University/CNRS/INRA/ENS/EZUS/LST/Market Study /Alcimed/Incubator/ Incubation } \\
\text { agreement/ Zebrafish }\end{array}$ \\
\hline 5 & 16 & $\begin{array}{l}\mathrm{LS} / \mathrm{AB} / \mathrm{AC} / \mathrm{AD} / \mathrm{AE} \text { /Lab UCB/Université/CNRS/INRA/ENS/EZUS// Market Study /Alcimed/Incubateur/ Incubation } \\
\text { agreement / }\end{array}$ \\
\hline 6 & 0 & End \\
\hline \multicolumn{3}{|r|}{ Case 3: Reproxx } \\
\hline Version & $\begin{array}{l}\text { Network } \\
\text { Size }\end{array}$ & Network structure \\
\hline 1 & 1 & PV \\
\hline 2 & 7 & PV/ WF/ Director EM/ Incubator/ PPT Presentation/ BioM/ Director Bigpharma \\
\hline 3 & 11 & PV/ WF/ Director EM/ Incubator/ PPT Presentation/ BioM/ Unit R/ Inserm/ Director F1/ Labv/ Unceia \\
\hline 4 & 10 & PV/ WF/ Director EM/ Incubator/ PPT Presentation/ Unit R/ Inserm/ Director F1/ Labv/ Unceia \\
\hline 5 & 15 & $\begin{array}{l}\text { PV/ WF/ Director EM/ Incubator/ PPT Presentation/ Unit R/ Inserm/ Director F1/ Labv/ Unceia/Rhône Alpes Region/ } \\
\text { Antibodies/ Scientifics Rapports / Alcimed/ Market Study }\end{array}$ \\
\hline 6 & 17 & $\begin{array}{l}\text { PV/ WF/ Director EM/ Incubator/ PPT Presentation/ BioM/ Unit R/ Director F1/ Labv/ Rhône Alpes Region/ Antibodies/ } \\
\text { Scientifics Rapports / Alcimed/ Market Study /Scientific Comity/ Researcher/ Agreement/ Business Plan }\end{array}$ \\
\hline 7 & 19 & $\begin{array}{l}\text { PV/ WF/ Director EM/ Incubator/ PPT Presentation/ BioM/ Unit R/ Director F1/ Labv/ Rhône Alpes Region/ Antibodies/ } \\
\text { Scientifics Rapports / Alcimed/ Market Study /Scientific Comity/ Researcher/ Agreement/ Business Plan RR/Launcher }\end{array}$ \\
\hline 8 & 22 & $\begin{array}{l}\mathrm{PV} / \mathrm{WF} / \mathrm{Director} \mathrm{EM} \text { / Incubator/ PPT Presentation/BioM/ Unit R/ Director F1/Labv/ Unceia/Rhône Alpes Region/ Antibodies/ } \\
\text { Scientifics Rapports / Alcimed/ Market Study / Scientific Comity/ Researcher/ Agreement/ Business Plan } \\
\text { RR/Launcher/BA/ Réseau Entreprendre/End }\end{array}$ \\
\hline
\end{tabular}


$\underline{\text { Table } 4 \text { Socio-technical indicators }}$

\begin{tabular}{|c|c|c|c|c|c|c|c|c|c|c|c|c|}
\hline \multicolumn{13}{|c|}{ Case 1: SuperNova } \\
\hline Version & $\mathbf{S}$ & $\mathbf{A}$ & $\mathbf{N}$ & CNA & $\mathbf{E}$ & ANA & LNA & $T(N-1)$ & $\mathrm{A}(\mathrm{N}+\mathbf{1})$ & IN(n) & $\mathbf{Y}(\mathbf{n})$ & $\mathbf{R}(\mathbf{n})$ \\
\hline V1 & 1 & - & 1 & 1 & 1 & - & - & - & 1 & 1.00 & n.d & n.d \\
\hline V2 & 2 & 1 & 1 & 3 & 3 & 1 & 0 & 1 & 2 & 0.50 & 0.33 & 1.00 \\
\hline $\mathbf{V 3}$ & 3 & 2 & 1 & 6 & 8 & 1 & 0 & 2 & 3 & 0.33 & 0.13 & 1.00 \\
\hline V4 & 9 & 3 & 6 & 15 & 14 & 6 & 0 & 3 & 9 & 0.67 & 0.43 & 1.00 \\
\hline V5 & 18 & 9 & 9 & 33 & 32 & 9 & 0 & 9 & 18 & 0.50 & 0.28 & 1.00 \\
\hline V6 & 31 & 18 & 13 & 64 & 63 & 11 & 0 & 18 & 27 & 0.42 & 0.17 & 1.00 \\
\hline $\mathrm{V7}$ & 32 & 27 & 5 & 96 & 95 & 5 & 0 & 31 & 32 & 0.16 & 0.05 & 0.87 \\
\hline V8 & 48 & 32 & 16 & 144 & 143 & 16 & 0 & 32 & 48 & 0.33 & 0.11 & 1.00 \\
\hline V9 & 67 & 48 & 19 & 211 & 209 & - & 1 & 48 & - & 0.28 & n.d & 1.00 \\
\hline \multicolumn{13}{|c|}{ Case 2: Zebrafish } \\
\hline Version & $\mathbf{S}$ & $\mathbf{A}$ & $\mathbf{N}$ & CNA & $\mathbf{E}$ & ANA & LNA & $T(N-1)$ & $\mathrm{A}(\mathrm{N}+\mathbf{1})$ & IN(n) & $\mathbf{Y}(\mathbf{n})$ & $\mathbf{R}(\mathbf{n})$ \\
\hline V1 & 5 & - & 5 & 5 & 5 & - & - & - & 5 & 1.00 & n.d & n.d \\
\hline $\mathbf{V 2}$ & 12 & 5 & 7 & 12 & 12 & 5 & 0 & 5 & 7 & 0.58 & 0.42 & 1.00 \\
\hline V3 & 16 & 12 & 4 & 16 & 16 & 7 & 0 & 12 & 16 & 0.25 & 0.44 & 1.00 \\
\hline V4 & 17 & 16 & 1 & 17 & 17 & 4 & 0 & 16 & 17 & 0.06 & 0.24 & 1.00 \\
\hline V5 & 16 & 16 & 0 & 17 & 17 & 1 & 1 & 17 & 0 & 0.00 & 0.00 & 0.94 \\
\hline V6 & 0 & - & 0 & 17 & 17 & 0 & 16 & 16 & 0 & n.d & -0.94 & 0.00 \\
\hline \multicolumn{13}{|c|}{ Case 3: Reproxx } \\
\hline Version & $\mathbf{S}$ & $\mathbf{A}$ & $\mathbf{N}$ & CNA & $\mathbf{E}$ & ANA & LNA & $\mathrm{T}(\mathrm{N}-1)$ & $A(N+1)$ & IN(n) & $\mathbf{Y}(\mathbf{n})$ & $\mathbf{R}(\mathbf{n})$ \\
\hline V1 & 1 & - & 1 & 1 & 1 & - & - & - & 1 & 1.00 & n.d & n.d \\
\hline V2 & 7 & 1 & 6 & 7 & 7 & 1 & 0 & 1 & 7 & 0.86 & 0.14 & 1.00 \\
\hline V3 & 11 & 7 & 4 & 11 & 11 & 6 & 0 & 7 & 9 & 0.36 & 0.55 & 1.00 \\
\hline V4 & 10 & 9 & 1 & 12 & 12 & 3 & 0 & 11 & 10 & 0.10 & 0.25 & 0.82 \\
\hline V5 & 15 & 10 & 5 & 17 & 17 & 1 & 0 & 10 & 12 & 0.33 & 0.06 & 1.00 \\
\hline V6 & 17 & 12 & 5 & 22 & 22 & 4 & 0 & 15 & 17 & 0.29 & 0.18 & 0.80 \\
\hline V7 & 19 & 17 & 2 & 24 & 24 & 5 & 0 & 17 & 19 & 0.11 & 0.21 & 1.00 \\
\hline V8 & 22 & 19 & 3 & 26 & 25 & 2 & 0 & 19 & - & 0.14 & 0.08 & 1.00 \\
\hline
\end{tabular}


Table 5 Entrepreneurial actor-network entities and their roles

\begin{tabular}{|c|c|c|c|}
\hline Artefacts & Phases & Description & Role and outcomes \\
\hline $\begin{array}{l}\text { PowerPoint } \\
\text { slides (PPT) }\end{array}$ & 1 & $\begin{array}{l}\text { A PPT slideshow prepared and } \\
\text { presented by the entrepreneur to an } \\
\text { incubator selection jury }\end{array}$ & $\begin{array}{l}\text { Enabled the entrepreneur to access } \\
\text { incubator services and facilities, pending } \\
\text { technological validation of his invention }\end{array}$ \\
\hline $\begin{array}{l}\text { Video } \\
\text { recordings }\end{array}$ & 1 and 2 & $\begin{array}{l}\text { The first video (Supernova) } \\
\text { demonstrated the technical } \\
\text { feasibility of the products. The } \\
\text { second video demonstrated } \\
\text { repeated technical performances } \\
\text { The Zebrafish video demonstrated } \\
\text { the potential of the transgenic } \\
\text { Zebrafish to develop candidate } \\
\text { molecules for drug development }\end{array}$ & $\begin{array}{l}\text { Changed people's perceptions of the project } \\
\text { and mobilized interest and commitment } \\
\text { Reduced information asymmetry between } \\
\text { the nascent entrepreneur and network } \\
\text { members } \\
\text { Created new social ties }\end{array}$ \\
\hline $\begin{array}{l}\text { Prototypes } \\
\text { and } \\
\text { algorithms }\end{array}$ & 2 and 3 & $\begin{array}{l}\text { Different prototypes of the product, } \\
\text { each with increasing technological } \\
\text { sophistication }\end{array}$ & $\begin{array}{l}\text { Demonstrated technological progression of } \\
\text { the project and the capacity of the } \\
\text { entrepreneurs to achieve their aims. } \\
\text { Increased legitimacy, reputation and self- } \\
\text { confidence of the nascent entrepreneur }\end{array}$ \\
\hline Award & 3 & $\begin{array}{l}\text { Application that won the OSEO } \\
\text { award }\end{array}$ & $\begin{array}{l}\text { Played an intermediary role with the } \\
\text { financial actors and enabled the } \\
\text { entrepreneur to access a prize fund of } \\
€ 380,000 \text { (SuperNova) and } € 40,000 \\
\text { (Reproxx). }\end{array}$ \\
\hline Zebrafish & $\begin{array}{l}1-2 \\
\text { and } 3\end{array}$ & $\begin{array}{l}\text { The entrepreneur needs to develop } \\
\text { different generations of Zebrafish } \\
\text { (F0, F1, F2, etc.), however the } \\
\text { transgenic fish "refused" to } \\
\text { collaborate. }\end{array}$ & $\begin{array}{l}\text { Due to their behavior, the Zebrafish } \\
\text { prevented the entrepreneurial process from } \\
\text { moving forward } \\
\text { Entrepreneurial failure }\end{array}$ \\
\hline Antibodies & $\begin{array}{l}1-2 \\
\text { and } 3\end{array}$ & $\begin{array}{l}\text { The antibodies have specific } \\
\text { characteristics useful for the } \\
\text { development of a quick test for } \\
\text { measuring progesterone } \\
\text { concentration in milk or blood }\end{array}$ & $\begin{array}{l}\text { They accelerate or delay the rhythm of the } \\
\text { entrepreneurial activities } \\
\text { Added further uncertainty and complexity }\end{array}$ \\
\hline $\begin{array}{l}\text { Business } \\
\text { plans }\end{array}$ & 1 & $\begin{array}{l}\text { Business plan developed with } \\
\text { incubator mentor }\end{array}$ & $\begin{array}{l}\text { Demonstrated the value creation } \\
\text { opportunity } \\
\text { Played an intermediary role with the } \\
\text { financial actors and enabled the } \\
\text { entrepreneur to access significant resources }\end{array}$ \\
\hline $\begin{array}{l}\text { Scientific } \\
\text { committee }\end{array}$ & 3 & $\begin{array}{l}\text { A strategic committee composed } \\
\text { by the key actors to advise the } \\
\text { entrepreneur }\end{array}$ & $\begin{array}{l}\text { Created an artificial environment for } \\
\text { common work, a "strategic space" } \\
\text { Reduced a conflicting interest within } \\
\text { network members }\end{array}$ \\
\hline $\begin{array}{l}\text { Collaborative } \\
\text { project }\end{array}$ & 3 & $\begin{array}{l}\text { Collaboration agreement between } \\
\text { the entrepreneur and scientific } \\
\text { institutions } \\
\text { Incubation agreement }\end{array}$ & $\begin{array}{l}\text { Mobilized interessement and commitment } \\
\text { of key actors. Promoted social interactions }\end{array}$ \\
\hline
\end{tabular}




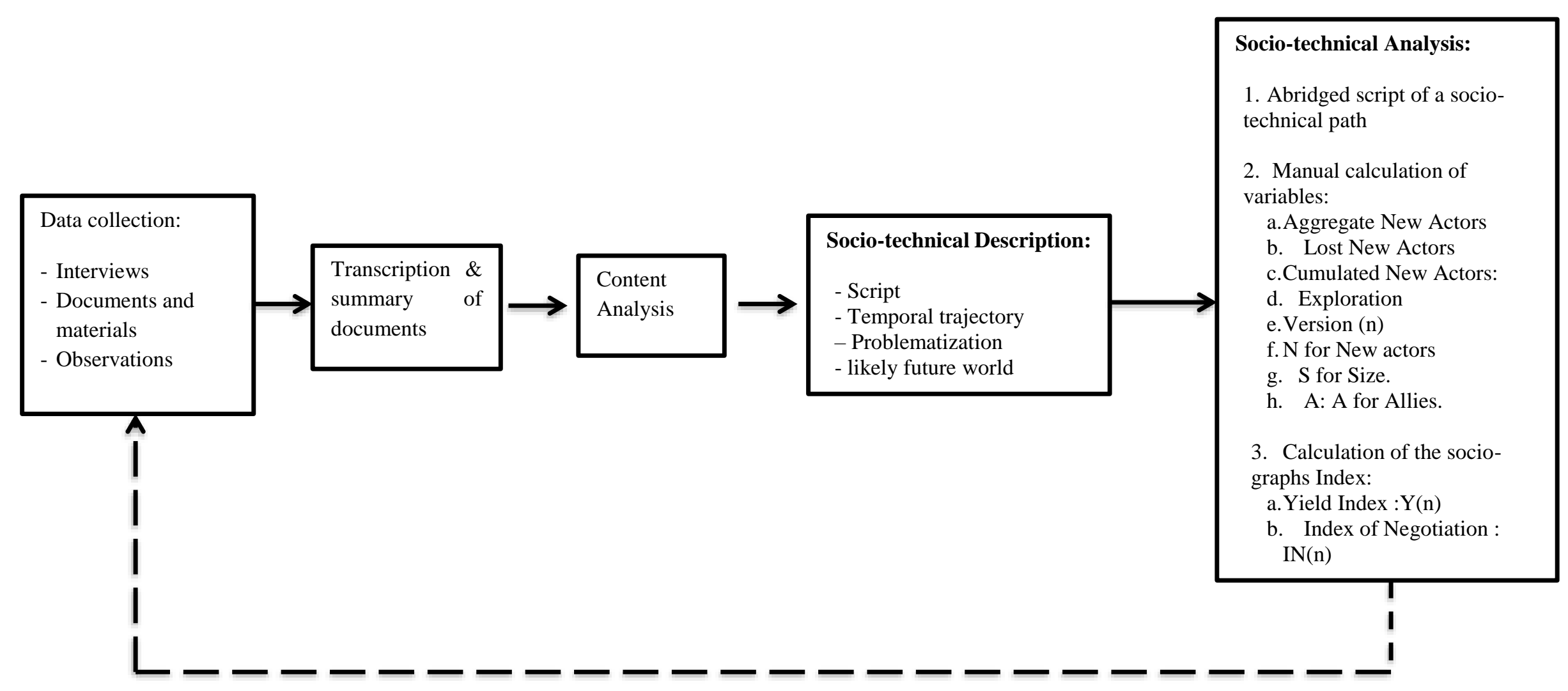




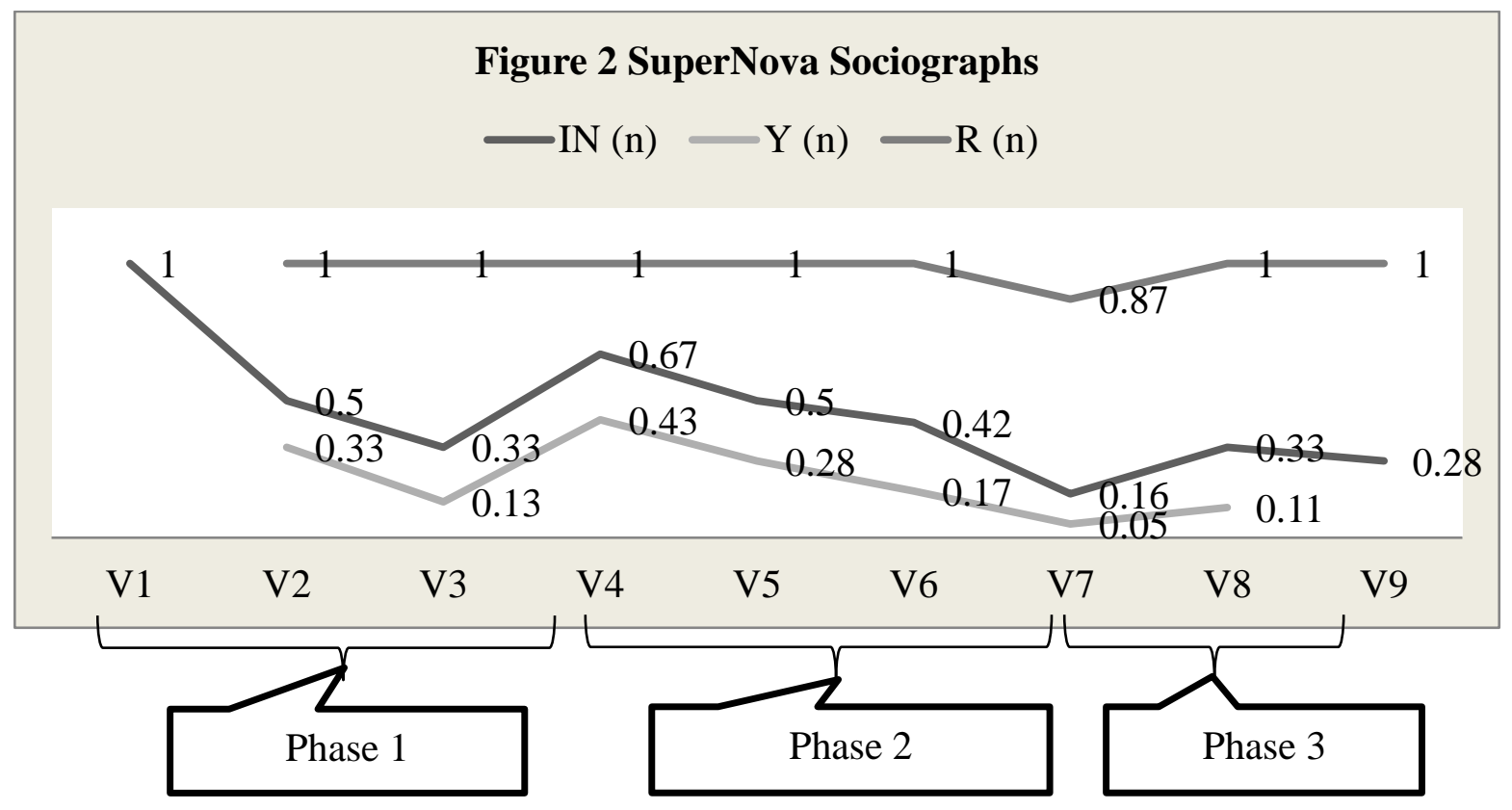

Figure 3 Zebrafish Sociographs

$\longrightarrow \mathrm{IN}(\mathrm{n}) \longrightarrow \mathrm{Y}(\mathrm{n}) \longrightarrow \mathrm{R}(\mathrm{n})$

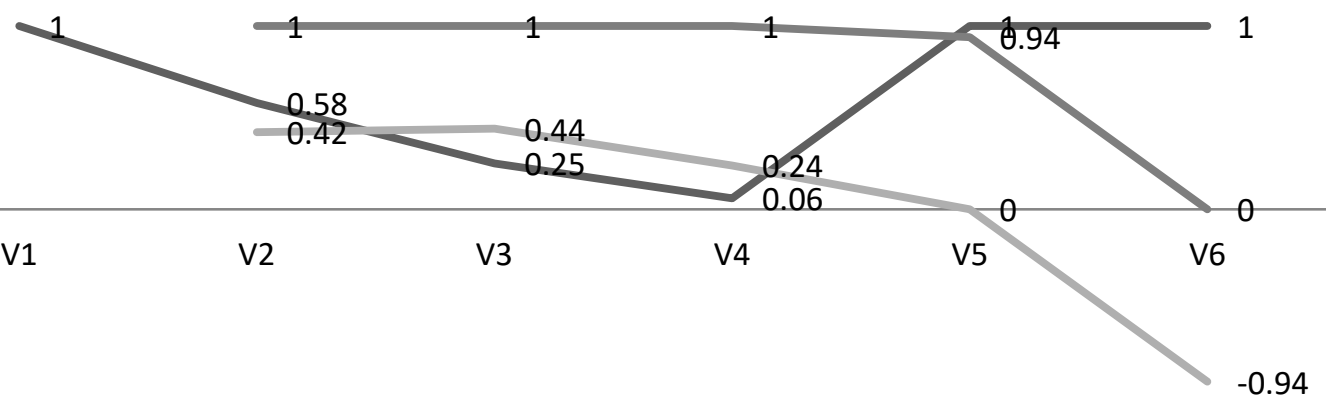

$-0.94$

Phase 1

Phase 2 


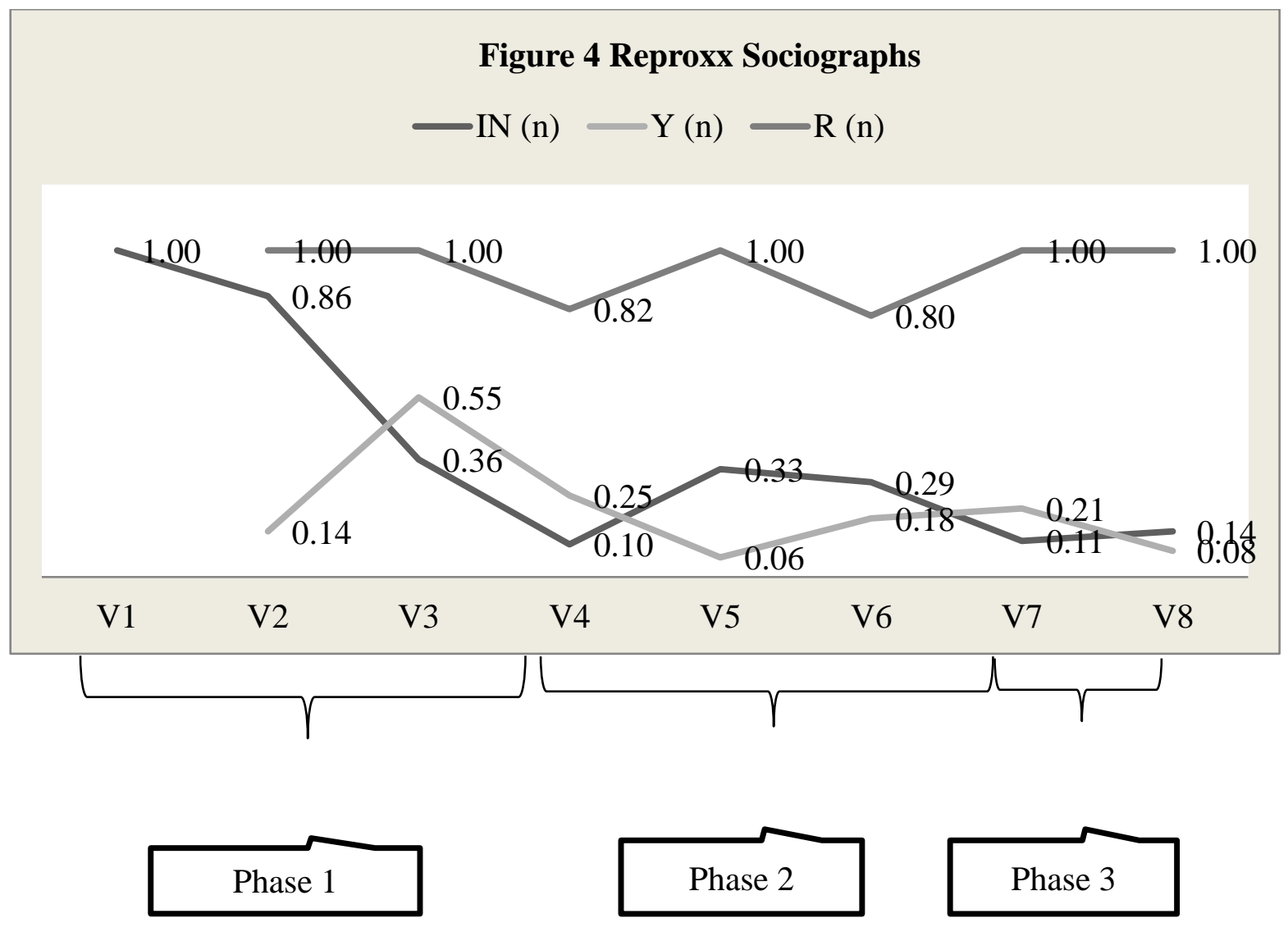




\section{Appendix 1:}

- Yield Index: Y(n) $=\left(\sum\right.$ ANA $)-\left(\sum\right.$ LNA $) / \mathbf{E}(\mathbf{n})$

- Index of Negotiation: $I N(n)=N(n) / S(n)$ with $S(n)=A(n)+N(n)$

- Index of Reality: $R(n)=A(n) / S(n-1)$

\section{With:}

- ANA = Aggregate New Actors

- LNA = Lost New Actors

- CNA = Cumulated New Actors: indicates the variation of the degree of attachment of the actors to the project

- E = Exploration is a synthetic indicator that distinguishes innovations that involve a large number of new actors from those that recombine a small number of potential allies in different network's configurations

- $\mathbf{n}=$ Version of socio-technical network (n)

- $\mathbf{N}=$ New actors (actors recruited in moving from one version of socio-technical to another)

- $\mathbf{S}=$ Size (the number of associated elements in each successive version of socio-technical network)

- A = Allies (the number of elements maintained from one version of socio-technical network to the next)

\section{Calculating the indicators: Detailed example of SuperNova}

These indicators were calculated using Latour et al., (1992).

The first indicator is $\mathbf{S}$, which denotes the number of associated entities in each successive version of the socio-technical network. The second indicator is $\mathbf{A}$, which compares the number of elements maintained from one version of network to the next. The third indicator is $\mathbf{N}$, new actors recruited in moving from one version to another. For each version, identified by a subscript $\mathbf{n}$, we thus obtain:

$\mathbf{S}(\mathbf{n})=\mathbf{A}(\mathbf{n})+\mathbf{N}(\mathbf{n})$. For example: $\mathbf{S}(9)=48+19=67$

\section{Index of Negotiation (IN)}

Thanks to these first three indicators we can define IN:

$\mathbf{I N}(\mathbf{n})=\mathbf{N}(\mathbf{n}) / \mathbf{S}(\mathbf{n})$. For example: IN $(4)=6 / 9=0.67$

The smaller the value of this index, the less the entrepreneur has to negotiate to ensure the continued existence of his/her project. Conversely, a high value of this index means that the project has to be extensively renegotiated. For SuperNova, we obtained the following figures:

\begin{tabular}{|c|c|c|c|c|}
\hline $\begin{array}{c}\text { Version of } \\
\text { socio- }\end{array}$ & S & A & N & IN \\
\hline
\end{tabular}




\begin{tabular}{|c|c|c|c|c|}
\hline & & & & \\
\hline V1 & 1 & - & 1 & 1.00 \\
\hline V2 & 2 & 1 & 1 & 0.50 \\
\hline V3 & 3 & 2 & 1 & 0.33 \\
\hline V4 & 9 & 3 & 6 & 0.67 \\
\hline V5 & 18 & 9 & 9 & 0.50 \\
\hline V6 & 31 & 18 & 13 & 0.42 \\
\hline V7 & 32 & 27 & 5 & 0.16 \\
\hline V8 & 48 & 32 & 16 & 0.33 \\
\hline V9 & 67 & 48 & 19 & 0.28 \\
\hline
\end{tabular}

This table demonstrates that new actors can be (re)mobilized by a socio-technical network version (n) that had already been mobilized in previous versions. Thus the accumulation of new actors from one version to the next over a given period can be different from the total number of actors associated with the project during the same period. We emphasize the distinction between CNA and E. CNA denotes the variation of the degree of attachment of the actors, while $\mathbf{E}$ represents the size of the population of actors mobilized. $\mathbf{E}$ is a synthetic indicator that allows us to distinguish between projects that explore a large number of new actors and those that recombine a small number of potential allies in different configurations. Latour et al. (1992) used the following figure to distinguish CNA from $\mathbf{E}$ :

Difference between CNA and Exploration (Latour et al., 1992: 52)

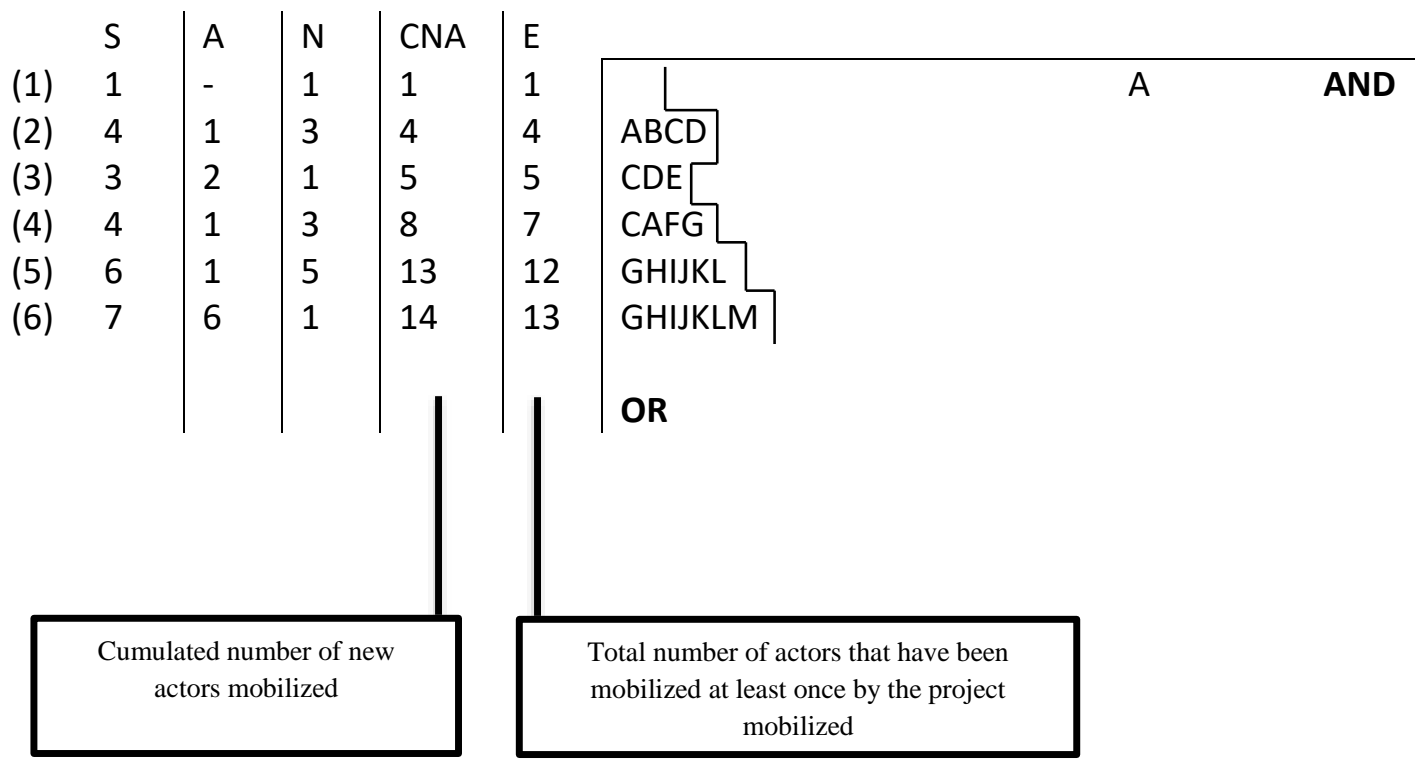

Some projects are strongly attractive to actors. This means that all the new actors that participated in the project at one point in a socio-technical network version (n) find themselves associated with the project 
again in the next version $(n+1)$. These actors constitute the aggregate of new actors: they are those who move from the index $N(n)$ to the index $A(n+1)$. Conversely, some of these new actors have disappeared in the $(n-1)$ version; these are the "lost" new actors. To measure the capacity of the project to attract most of the new actors it mobilizes, we calculate $\mathbf{Y}$.

$\mathbf{Y}$ is calculated by dividing [(the cumulative number of the aggregate of new actors) - (the cumulated number of lost new actors)] by $\mathbf{E}$. The indicator thus obtained measures either the capacity of a project to attach itself to the majority of the actors it mobilizes or, conversely, its tendency to be visited by a large number of new actors without fixing itself anywhere.

Yield Index: $\mathbf{Y}(\mathbf{n})=\left(\sum\right.$ ANA $)-\left(\sum\right.$ LNA $) / \mathbf{E}(\mathbf{n})$

where ANA = Aggregate of New Actors and LNA = Lost New Actors

This index takes values between 1 and -1 . For example: $Y(4)=(6-0) / 14=\mathbf{0 . 4 3}$

For SuperNova project, we obtain the following results:

\begin{tabular}{|l|r|r|r|l|}
\hline $\begin{array}{c}\text { Socio- } \\
\text { technical } \\
\text { network } \\
\text { version }\end{array}$ & Aggregate New Actors & Lost New Actors & Exploration & \multicolumn{1}{c|}{$\begin{array}{c}\text { Y(n) } \\
\text { Yield Indicator }\end{array}$} \\
\hline V1 & - & - & $\mathbf{1}$ & no data \\
\hline V2 & $\mathbf{1}$ & $\mathbf{0}$ & $\mathbf{3}$ & $(1-0) / 3=\mathbf{0 . 3 3}$ \\
\hline V3 & $\mathbf{1}$ & $\mathbf{0}$ & $\mathbf{8}$ & $(1-0) / 8=\mathbf{0 . 1 3}$ \\
\hline V4 & $\mathbf{6}$ & $\mathbf{0}$ & $\mathbf{1 4}$ & $(6-0) / 14=\mathbf{0 . 4 3}$ \\
\hline V5 & $\mathbf{9}$ & $\mathbf{0}$ & $\mathbf{3 2}$ & $(9-0) / 32=\mathbf{0 . 2 8}$ \\
\hline V6 & $\mathbf{1 1}$ & $\mathbf{0}$ & $\mathbf{6 3}$ & $(11-0) / 63=\mathbf{0 . 1 7}$ \\
\hline V7 & $\mathbf{5}$ & $\mathbf{0}$ & $\mathbf{9 5}$ & $(5-0) / 95=\mathbf{0 . 0 5}$ \\
\hline V8 & $\mathbf{1 6}$ & $\mathbf{0}$ & $\mathbf{1 4 3}$ & $(16-0) / 143=\mathbf{0 . 1 1}$ \\
\hline V9 & - & $\mathbf{1}$ & $\mathbf{2 0 9}$ & no data \\
\hline
\end{tabular}

A final synthetic index can be obtained by dividing the number of associated elements (A) that remain stable in a version $(\mathbf{n})$ by the size $(\mathbf{S})$ of the previous version $(n-1)$. This index defines $\mathbf{R}$, that is, the resistance it needs to be able to move from one version of network to the next without putting what it already acquired into question:

$\mathbf{R}(\mathbf{n})=\mathbf{A}(\mathbf{n}) / \mathbf{S}(\mathbf{n}-\mathbf{1})-$ Example $\mathrm{R}(7)=27 / 31=0.87$ 


\begin{tabular}{|c|r|r|r|}
\hline $\begin{array}{c}\text { Socio- } \\
\text { technical } \\
\text { network } \\
\text { Version }\end{array}$ & $\begin{array}{c}\text { A } \\
\text { Allies }\end{array}$ & S (N-1) & $\begin{array}{c}\text { R(n) } \\
\text { Indicator of } \\
\text { Reality }\end{array}$ \\
\hline V1 & - & - & \\
\hline V2 & $\mathbf{1}$ & $\mathbf{1}$ & 1.00 \\
\hline V3 & $\mathbf{2}$ & $\mathbf{2}$ & 1.00 \\
\hline V4 & $\mathbf{3}$ & $\mathbf{3}$ & 1.00 \\
\hline V5 & $\mathbf{9}$ & $\mathbf{9}$ & 1.00 \\
\hline V6 & $\mathbf{1 8}$ & $\mathbf{1 8}$ & 1.00 \\
\hline V7 & $\mathbf{2 7}$ & $\mathbf{3 1}$ & 0.87 \\
\hline V8 & $\mathbf{3 2}$ & $\mathbf{3 2}$ & 1.00 \\
\hline V9 & $\mathbf{4 8}$ & $\mathbf{4 8}$ & 1.00 \\
\hline
\end{tabular}

